\title{
Processes in informal end-processing of e-waste generated from personal computers in Vietnam
}

\author{
Chung Duc Tran ${ }^{1,2} \cdot$ Stefan Petrus Salhofer ${ }^{1}$
}

Received: 31 January 2017 / Accepted: 25 October 2017 / Published online: 3 November 2017

(C) The Author(s) 2017. This article is an open access publication

\begin{abstract}
Informal treatment of e-waste plays an important role in many countries which have no or weak formal waste management structures. One of the challenges for assessing informal e-waste recycling technologies is to identify their disadvantages and potential technology improvement. The analysis of informal recycling processes starts with a balance of input and output materials for each of the processes. Main obstacles are the fact that in most cases, mixed or variety materials serve as input and, secondly by nature, the informal sector does not systematically measure and monitor the process. This study presents the processes and available data for informal e-waste recycling of desktop personal computer as it consists of components made of plastic and many metals within the Vietnamese context. To identify the most relevant processes, critical flows and technology gap, two scenarios are compared: (1) current situation in which recycling activities are taken in recycling craft villages and (2) appropriately selected BAT. The selected materials from e-waste cover a wide range of recycling processes and technologies: Printed Circuit Board treatment, metal (ferrous metal, aluminum and copper) and plastic recycling.
\end{abstract}

Keywords Vietnam - e-waste - e-waste from personal computer $\cdot$ Informal recycling $\cdot$ Craft villages

Chung Duc Tran

tranducchung@gmail.com;

tranducchung@students.boku.ac.at

1 Department of Water-Atmosphere-Environmen, Institute of Waste Managementt, University of Natural Resources and Life Sciences, Muthgasse 107, 1190 Vienna, Austria

2 Vietnam Cleaner Production Centre, Rm. No. 228B, Ta Quang Buu E-Library, Hanoi University of Science and Technology, Hanoi, Vietnam

\section{Introduction}

Advanced technologies have led to dramatical demand in electrical and electronic equipment (EEE) but shortened their lifespan as well. Consequently, more waste from electrical and electronic equipment, e-waste or WEEE, is generated. From the global perspective, the total amount of e-waste generated in 2014 was 41.8 million metric tonnes (Mt) and predicted to increase to $50 \mathrm{Mt}$ in 2018 [1]. e-waste contain metals (ferrous and non-ferrous metals) and other materials (e.g., plastics, glass) with full potential to be recycled. Unlike other materials, metals have virtually infinity lifespan and limitless recyclability [2]. Hence, recycling metals (and other materials) can provide numerous to not only environment advantages in terms of energy saving, reduction of waste and emissions but also economic benefits. For example, using scrap iron and steel helps to save $74 \%$ of energy, $90 \%$ of virgin material use and reduce air pollution, water use, water pollution, mining waste is at $86,40,76$ and $97 \%$, respectively, compared to primary production. Energy savings from recycled materials over virgin ones are $95 \%$ for aluminum, $85 \%$ for copper and above $80 \%$ for plastics [3].

In Vietnam, with the population is about 91.7 million in 2015 [4], Tran and Salhofer [5] using data from URENCO [6] estimated that e-waste generation from used EEE is roundly $1.9 \mathrm{~kg} / \mathrm{inh}$ abitant in 2014 and will be increased to $3.7 \mathrm{~kg} /$ inhabitant in 2020 [5]. As formal recycling facilities are lacking, e-waste treatment relies on informal sector. Due to the important role of this sector, many researchers have come up with varied definitions of "informal sector". For example, Feige [7] expresses that "the informal economy comprises those economic activities that circumvent the costs and are excluded from the benefits and right incorporated in the laws and administrative rules covering property relationships, commercial licensing, labor contracts, torts, 
financial credit and social security systems". Scheinberg et al. [8] define the informal solid waste sector as it "refers to individuals or enterprises who are involved in private sector recycling and waste management activities which are not sponsored, financed, recognized, supported, organized or acknowledged by the formal solid waste authorities, or which operate in violation of or in competition with formal authorities". In Vietnam, unlike formal sector which is established from hazardous waste treatment and transportation companies certified by Vietnam Environment Administration (VEA) having e-waste treatment system, informal sector is fast developed with an effective and active system which includes e-waste collection, transportation, trade, dismantling and end-processing. The most remarkable characteristic of the informal sector is the formation of craft villages-villages where residents have involved in industrial activities for their main income [5]. And, informal e-waste recycling has strong involvement of dismantling and recycling craft villages. Although the infrastructure for end-processing is available, large amount of outputs from dismantling process [e.g., ground Printed Circuit Boards (PCBs), capacitors, transistors, plastics] are exported to China because of price and domestic demands. For example, the highest domestic demand is plastic bags made of polyethylene-PE while plastics from e-waste sources consist mainly of acrylonitrile butadiene styrene-ABS, polystyrene-PS. Currently, PCBs are treated to recover copper in one workshop via mechanical processes in Bui Dau village (Hung Yen province). Components with high gold content are treated at few very small-sized workshops scattered in Bac Ninh province and Hai Phong city. Other materials, including ferrous metal, copper, aluminum and plastics, are recycled at craft villages under obsolete technologies. As these technologies pose a high risk for workers and the environment, this paper aims at evaluating the current recycling technologies and identifying the technology gap between the current with better ones.

The selected technologies for reference to the current technologies are best available techniques (BAT). BAT mean "the latest stage of development (state of the art) of processes, of facilities or of methods of operation which indicate the practical suitability of a particular measure for limiting discharges, emissions and waste" [9]. Within the BAT reference documents, techniques to consider in the determination of BAT are provided, from the material storage and handling process, material treatment, processing until waste treatment and/or residue processing. In fact, BAT are normally combined with the term best environmental practices (BEP) which is defined as "the application of the most appropriate combination of environmental control measures and strategies" [9]. It is very common to use BAT/ BEP as a target for technology improvement or technology evaluation. Benchmark data on material and energy consumption, and waste generation from BAT and practices from BEP are popular indication for technology gap assessment. Some examples are the Technical booklet "Applying BAT and BEP to eliminate persistent organic pollutants in steel-making process-electric arc furnace (EAF) [10] for Vietnamese steel manufacturers, or BAT for Indian Iron and Steel Sector [11].

In this study, desktop personal computers (PC) waste (without monitors and external accessories: mouse, keyboards, etc.) has been selected as a case study to analyze treatment processes in the context of Vietnam. In terms of product put on domestic market, estimated growth rate of PCs is approximately $20 \%$ annually [6]. Moreover, in terms of composition, whole PC consists of various materials: base (e.g., iron, aluminum, zinc), special (e.g., tellurium, selenium) and specious (e.g., gold, silver) metals, plastics, etc. Generally, PC waste can contain more than $69 \mathrm{wt} \%$ of iron and steel, non-ferrous metals such as copper (more than $4 \mathrm{wt} \%$ ), aluminum (more than $5 \mathrm{wt} \%$ ), zinc, and precious metals (e.g., Au, Ag, Pd) and plastics (e.g., ABS, ABS/PC, PS, PVC) [12]. Thus, outputs from PC dismantling cover comprehensive processing techniques: PCBs are partly treated for copper and gold recovery; metals (ferrous metal, aluminum and copper) and plastics are recycled at craft villages $[5,13,14]$.

\section{Materials and methods}

A literature review was conducted to describe the complexity of informal e-waste recycling and end-processing in Vietnam. However, there are a limited number of paper that could be found via databases, such as Scopus ${ }^{\circledR}$ or ScienceDirect, specifically addressing this topic in Vietnam. Thus, reports from national projects, studies from other organizations, cleaner production assessment reports, personal communication (e.g., via email, telephone, discussion) and observation during field trips to recycling workshops and craft villages have been utilized for process and data collection. The biggest project focusing on craft villages in Vietnam was the national-level project titled "scientific and realistic basic research for building up policies and solutions for environmental issues in craft villages of Vietnam" in 2005 from Institute for Environmental Science and Technology (INEST). Later, the Ministry of Natural Resources and Environment (MONRE) published the "National state of environment" report with theme "Vietnam craft village environment", together with Vietnam national environment report in 2008. In the Vietnam national environment report 2011, solid waste from those craft villages had been brought up again as a part of national solid waste management system. Evaluation on current situation of technology level and pollution at craft villages has been summarized the report on "National 
state of environment in the period of 2011-2015" from MONRE which is considered as the most up-to-date source of information. The data referred from these reports have been crosschecked and updated with other studies such as study from Vietnam Steel Association for steel recycling technologies, National Institute for Environmental Studies of Japan (NIES) and INEST on Classification of e-waste processing technology in Vietnam, cleaner production guidebook for metal processing from Ministry of Industry and Trade, and cleaner production assessment reports which are a part of cleaner production-energy efficiency consultancy work of the authors at the Vietnam Cleaner Production Centre for aluminum (e.g., summarization of the implementation of cleaner production assessment and hazardous waste management report at Van Chang craft village, cleaner production assessment report at Quang Dung private manufacturer), steel (e.g., cleaner production assessment reports at Dai Thang Casting Co., Ltd., VietPhap Steel Co., Ltd., workshops in Da Hoi craft villages) and plastic (e.g., cleaner production assessment reports at My Hung Co., Ltd., Nguyen Tan Production and Trading Private Enterprise) recycling processes and technologies. Other information has been observed and extracted during the field trips to craft villages such as Ngu Xa (a traditional copper casting village) in Hanoi, Bui Dau (an e-waste dismantling village) and Phan Boi (a plastic recycling village) in Hung Yen province.

As a part of this study is to compare the current recycling technologies with appropriate BAT, the BAT reference documents, or the so-called BREFs by Joint Research Centre of European Commission, together with Ecoinvent report v2.2 (under the license of Institute of Waste Management, University of Natural Resources and Life Sciences, Vienna-ABF-BOKU) have been used as the main information sources.

This study is also used STAN (subSTance flow ANalysis), a freeware developed by Institute for Water Quality, Resource and Waste Management of TU Vienna (Austria) for the flowchart of material flow analysis.

\section{Scenario analysis}

The informal e-waste treatment in Vietnam was counted for approximately $30 \mathrm{craft}$ villages handling e-waste recycling [15] out of 90 waste recycling villages mainly from the North in total 5096 craft villages in Vietnam [16]. e-waste treatment comprises four main steps: (1) collection and transportation, (2) reuse and refurbishment, (3) dismantling and pre-processing and (4) end-processing steps [5] as described in the studies of NIES and INEST [13] or Hai et al. [14]. For personal desktop (PC) case, the PC e-waste treatment steps are presented in Fig. 1.

As seen in Fig. 1, features of the first 3 steps (rectangular on the left) have been studied in the work of Tran and Salhofer [5] on how e-waste has been collected, reused parts and refurbished devices, and outputs from dismantling of specific electronic equipment. It is noted that untradeable materials (e.g., plastic foam, hard black plastic) are disposed (then dumped or landfilled) and a part of other components/materials (e.g., PCBs, plastics) are exported. In this study, the focus lies on the end-processing/recycling step (rectangular on the right of Fig. 1). Informal recycling activities involve recycling craft villages where metal and plastic scraps are processed. For PCB treatment, it involves not only the gold and copper recovery but also exportation (or dispose) of other electronic components (such as capacitors, transistors) mainly to China. Due to operating at small size, obsolete technologies and limited capacity for cleaner technology investment and waste treatment facilities [16], negative impacts to environment and human health are inevitable. Those impacts have been investigated by several studies, such as the work of the Vietnam Ministry of Natural Resources and Environment [17, 18], the study of Dang [19] and Dang et al. [16]. To cope with the current situation, local authorities (People's Committee at provincial, district and commune level) have issued several decisions, e.g., Decision number 396/QĐ-UBND of Bac Ninh People's Committee, Decision number 44/2008/QĐ-UBND of Hanoi People's Committee, on planning of industrial clusters and
Fig. 1 e-waste treatment steps in Vietnam (adapted from [13, 14])

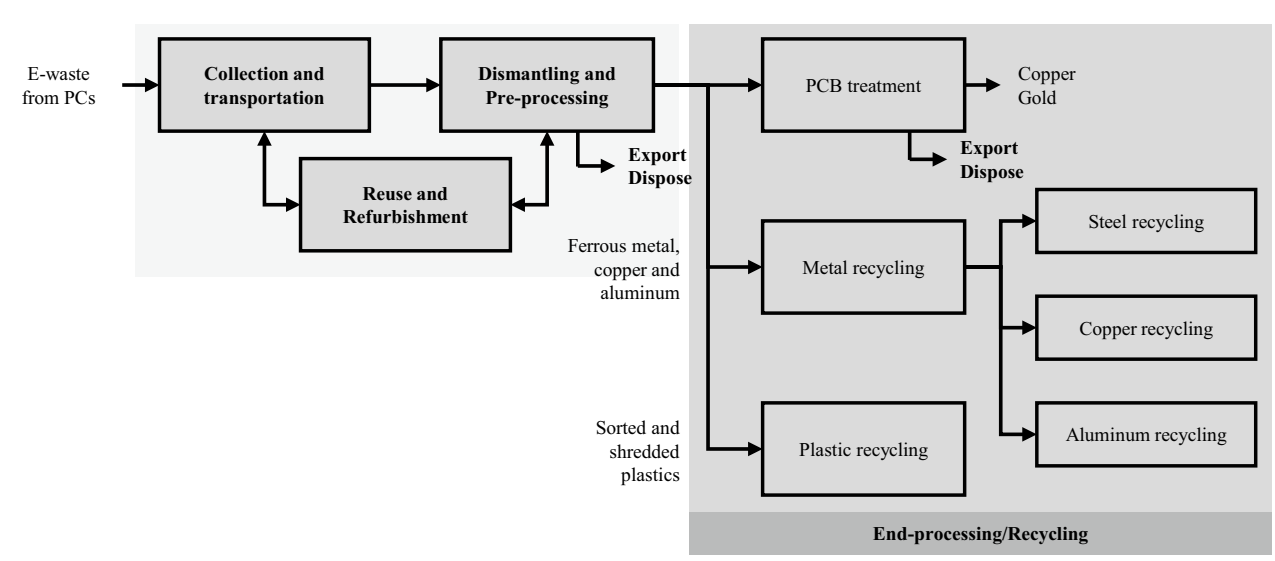


clusters of producers at craft villages. One important aspect of those plans is that processors at craft villages are supported and encouraged to transfer to centralized workshops with appropriate air and wastewater treatment facilities (e.g., bag filtration, sedimentation, filtration, chemical treatment of wastewater). To analyze the existing technology and to identify improvement potentials, in this study, two scenarios are compared:

- Scenario 1: Current situation. In this scenario, the current situation in which present technologies, input and output data from recycling/end-processing of e-waste has been investigated. Dismantled fractions (plastic, ferrous metal, copper and aluminum) are transported to and recycled at craft villages while PCBs are treated partly for gold and copper recovery. The remaining electronic components (e.g., capacitors, transistors) are exported. Collecting data for this scenario are a challenge as there are very limited number of published articles regarding the informal recycling processes. As stated above in the "Materials and methods", alternative available sources of information have been used. Data on dust, metal fume, other gases $\left(\mathrm{NO}_{x}, \mathrm{SO}_{2}\right.$, organic compounds) from melting process are not available as no air treatment facilities are installed and missing of input composition analysis. The only available data are some air quality monitoring reports for craft villages from study of Dang [19], MONRE [17] or Dang et al. [16] but those data were not able to interpolate to air emissions from generated pollution sources. As evaluated by Dang et al. [16], air pollution at craft villages has not been reduced but it tends to increase.

- Scenario 2: Selected BAT. This scenario presents a proposed situation in which, enterprises involved in e-waste end-processing (recycling of metals, PCBs and plastic) are gathered to centralized workshop. Each of them operates separately under selected BAT with BEP by sharing one or more waste treatment facilities. Except for the case of PCB recycling, in which the referred BAT are the current one at Umicore; other selected BAT are based on the following criteria: (1) suitable for recycled materials from e-waste sources; (2) technically upgradable for recyclers/smelters at craft villages; and (3) appropriate for Vietnamese context. The main data sources for selected BATs come from BAT references $[20,21]$ and data from ecoinvent reports [22-24]. Air emission from melting operations of smelters is available but depending on input materials (feeding capacity, scrap quality), air treatment technologies, air sucking capacity (volume of sucked air per hours). With appropriate treatment facilities, selected BAT and implemented BEP, emission to air, water and soil supposes to be satisfied environmental standards to be discharged into environment.
By comparing both scenarios, the technology gap shall be highlighted. Moreover, it also reveals the potentials such as energy saving, product quality improvement, cleaner technology upgrade, better process control, and good housekeeping. Based on the limited information, together with literature, air pollution, wastewater and solid waste are identified and summarized. Those emissions pose serious problems to not only workers but also residents living in craft villages. Unfortunately, they were not able to quantify. Only equivalent $\mathrm{CO}_{2}$ emission is calculated as emission to air.

\section{Process and data collection}

\section{Dismantling of desktop PC}

The informal dismantling processes have been provided in the studies of NIES and INEST [13], Hai et al. [14] with mainly manual works. The outputs include untradeable parts (e.g., foamed plastics, papers, glasses, batteries) which will be dumped or landfilled, metal fractions (copper, aluminum, zinc and ferrous metal), PCBs, plastic and cable fraction. The cables (e.g., power cables, color ribbon cables) are collected for cable treatment (copper and plastic separation). As observed from a workshop at Bui Dau village (Hung Yen province), cables are collected, sorted by diameters and treated by cable treatment machine using blades to strip and cut wires (recent common treatment method) or open-burning (less common practice) for copper extraction. Due to the presence of several types of cables with a high share of color ribbon cables in PCs, the overall copper content extracted from cables is about 13.5 percentage of total weight of processed cables. The rest is a mixture of plastics and other materials (such as fluoropolymers, polyamides [24]). The extracted copper is collected for copper recycling (added to copper proportion) and the rest is transferred to plastic recycling (added to plastic group). Material composition of PCs used in this study has been provided by Peter Beigl from Institute of Waste Management, University of Natural Resources and Life Sciences, Vienna (via personal communication) using the systematic examination of electronic appliances [25]. The output materials are presented in Table 1. As seen in Table 1, the ferrous metal has the highest proportion while copper and aluminum and zinc have the smallest mass percentage.

\section{Energy sources}

Energy is very important for end-processing/recycling as most recycling steps demand energy. The most used energy sources are electricity, coal, liquefied petroleum gas (LPG) and wood. This section presents Vietnamese electricity grid, properties of fuels and emissions from using them. 
Table 1 Output material groups from manual dismantling work at craft village

\begin{tabular}{lc}
\hline Regrouped materials & $\begin{array}{l}\text { Mass } \\
\text { percentage } \\
(\%)\end{array}$ \\
\hline Untradeable & 4.08 \\
Ferrous metals & 76.22 \\
Plastic & 8.08 \\
PCBs & 9.01 \\
Copper & 0.80 \\
Aluminum + zinc $^{\mathrm{a}}$ & 1.80 \\
Total & 100.0 \\
\hline
\end{tabular}

${ }^{\mathrm{a}}$ Going to aluminum recycling

Table 2 Vietnam power grid in 2014 [26]

\begin{tabular}{ll}
\hline Power source & $2014(\%)$ \\
\hline Hydropower & 40 \\
Coal-based thermal & 28 \\
Gas turbine & 22 \\
Diesel, small-sized hydropower and wind & 5 \\
Fuel oil (FO) based thermal & 2 \\
Gas-based thermal & 1 \\
Imported source & 2 \\
\hline
\end{tabular}

For electricity, as of 2014, the main electricity sources were from hydropower, coal-based thermal power and gas turbine power at the rate of 40,28 and $22 \%$, respectively [26]. A small generated electricity came from wind, Diesel Oil-based thermal power plants and imported electricity (Table 2). The power development program to 2030 mentioned within the National energy development strategyrevision of power master plan VII from General Directorate of Energy showed the change in power generation sector with the major increase of coal based thermal power $(58 \%$ in 2030 and $60 \%$ in 2030) and the significant reduction of hydropower (25 and 12\% in 2025 and 2030, accordingly) [26].

To calculate the emission from electricity consumption, only equivalent $\mathrm{CO}_{2}$ emission is considered as other emissions are not available. The equivalent $\mathrm{CO}_{2}$ emissions coefficient per $\mathrm{kWh}$ of electricity for Vietnamese electricity grid, together with the $\mathrm{CO}_{2}$ emissions coefficients for coal and LPG, is presented in Table 3.

For fuels, the most common use is coal as observed in the case of copper and aluminum recycling at craft villages. The selected type of coal is lump coal, type $4 \mathrm{~b}$ at net calorific values of $28 \mathrm{MJ} / \mathrm{kg}$ and $78.4 \mathrm{wt} \%$ of carbon content [27]. LPG is also used for PCB treatment to recover copper at its net calorific value of $49.5 \mathrm{MJ} / \mathrm{kg}$ (propane-LPG). This value is calculated from 90,500 Btu/gal [28] and the density of propane LPG is about $0.51 \mathrm{~kg} / 1$ [29]. Besides coal and LPG, wood is also used for copper recycling process. Wood in this case is wood residues such as bark, sawdust, chips, wood trim with net calorific values at $10.5 \mathrm{MJ} / \mathrm{kg}$ (converted from $4500 \mathrm{Btu} / \mathrm{lb}$ [30] for wood residues having moisture content from 10 to $15 \%$ ). In this study, consumed fuels are provided in converted energy amount (MJ).

\section{Recycling processes and technologies}

In this section, both current recycling technologies and selected BAT of PCBs, ferrous metal, copper, aluminum and plastics are presented in detail of processes and input/ output tables. The calculation is based on 1 tonne ( $t$ ) of main input material.

\section{PCB treatment}

Current selected techniques The most common practices for PCB treatment at craft villages in Vietnam are (1) to separate and sort electronic components into several categories (ICs, transistors, capacitors) and (2) to shred the remain circuit boards for exporting purposes (mainly to China).

In this study, two current technologies for PCB treatment have been investigated: (1) gold recovery using aqua regia (Fig. 2) and (2) copper recovery using mechanical process (Fig. 3). For the composition of PCBs, data from Le et al. [32] have been used.

For gold recovery, few very small-sized workshops in the north treat high gold-contained parts (central processing units-CPUs and gold-plated connectors) for gold

Table 3 Carbon dioxide emissions coefficients

\begin{tabular}{llll}
\hline Energy type & Unit & $\begin{array}{l}\text { Equivalent } \mathrm{CO}_{2} \text { emis- } \\
\text { sion coefficient }\end{array}$ & References \\
\hline Electricity & $\mathrm{kg} \mathrm{CO}_{2} / \mathrm{kWh}$ & 0.4668 & {$[31]$} \\
Coal (lump coal, type 4b) & $\mathrm{kg} \mathrm{CO}_{2} / \mathrm{kg}$ & 28.7467 & $\begin{array}{c}\text { Calculated from the carbon constituent and oxidation reac- } \\
\text { tion of carbon }{ }^{\mathrm{a}} \text { at the assumption rate of } 100 \%\end{array}$ \\
Liquefied petroleum gas (LPG) & $\mathrm{kg} \mathrm{CO}_{2} / \mathrm{kg}$ & 2.86 & Calculated from LPG emission factor $12,500 \mathrm{lb} / 10^{3}$ gal $[28]$ \\
\hline
\end{tabular}

${ }^{\mathrm{a}} \mathrm{C}+\mathrm{O}_{2} \rightarrow \mathrm{CO}_{2}+$ energy 


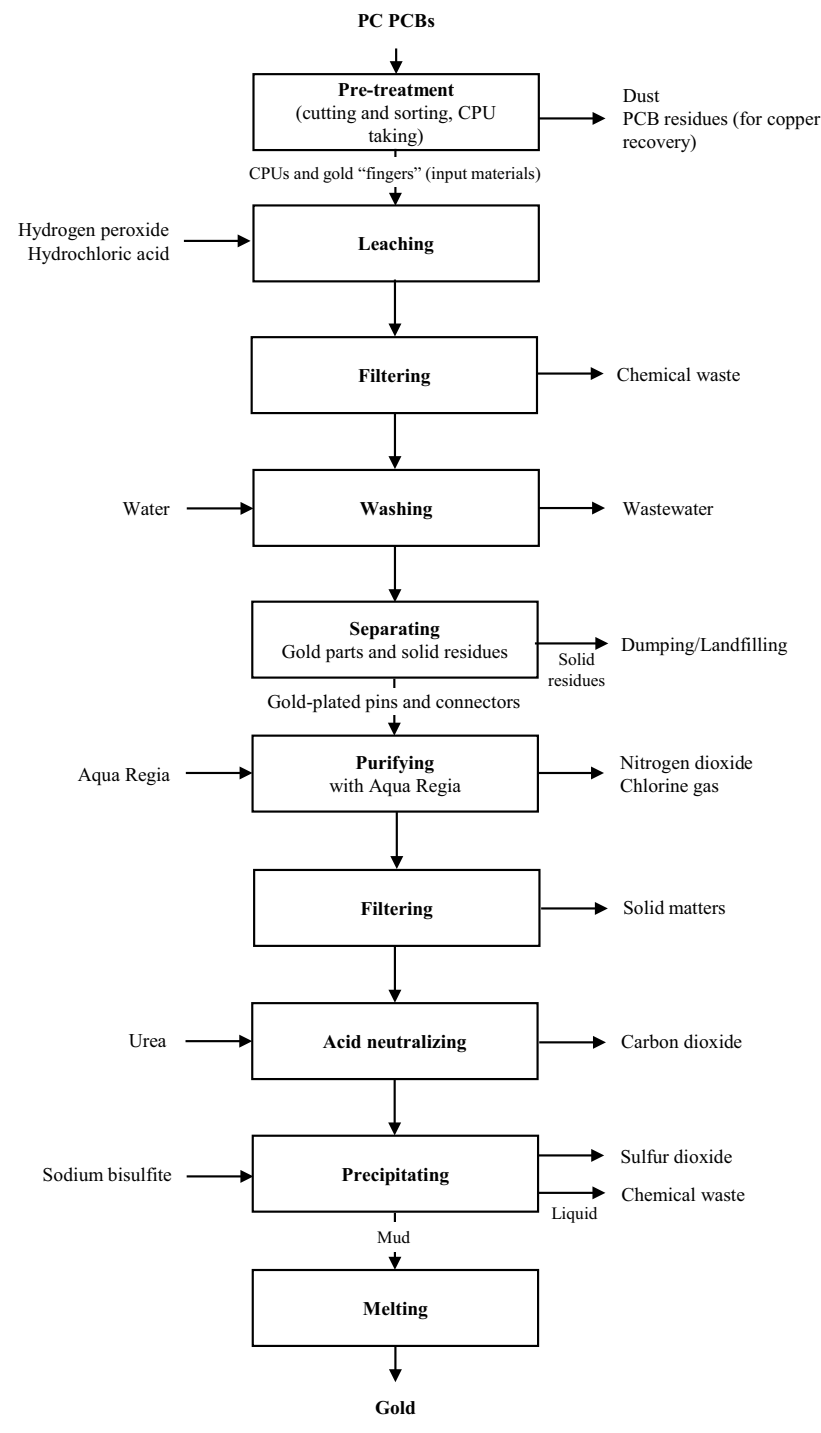

Fig. 2 Flowchart of gold recovery process from gold fingers and CPUs

recovery under acid bathing techniques (e.g., using aqua regia or using other chemicals before using aqua regia or other acid leaching methods) and accessing to these recyclers for information collection is very limited. Generally, the highest gold-contained parts in desktop PCs are CPUs with gold-plated pins but only ceramic types of CPUs have higher amount of gold (e.g., Toshiba, AMD K5, Pentium Pro, Cyrix 586, IBM 686) and they are easy to take out from motherboards by hands or screwdrivers. Other goldcontained parts include random access memory (RAM) modules, peripheral component interconnect (PCI) modules, sound cards, video graphics array (VGA) modules as they have gold-plated connectors. Those gold-plated connectors need to be cut out from boards using cutters or saws. Cut gold-plated connectors are called "gold fingers" as they have the bar shapes. A "good" cut of gold fingers leaves very small area of "green" board. Thus, the quality of gold fingers (how they are cut and thickness of gold-plated layer) is of importance to decide how much gold yield can get after processing. Gold is contained in gold-plated pins as well, such as CPU socket pins, test pins, connector pins and they require other tools to extract (screw drivers, hams).

The process of gold recovery is briefed in Fig. 2. The highest gold-contained parts after extracting from PCBs are leached in the mixture of hydrogen peroxide $\left(\mathrm{H}_{2} \mathrm{O}_{2}\right)$ and hydrochloric acid $(\mathrm{HCl})$ to dissolve copper and release goldplated connectors and pins. When gold-plated connectors and pins are collected by filtering and washing, they are purified with aqua regia. Only the solution is used to be neutralized with urea. Then, sodium bisulfite is added, mixed and waited to collect the precipitation. The precipitation is melted directly under fire from a gas blowtorch (blowlamps) to get pure gold.

The recovery rate of $25 \%$ was taken from studies of Keller [33] and Rochat [34]. A study from Williams et al. [35] summarizes that $58 \%$ of total gold remains in the circuit board and 5\% of total gold is emitted as dust during separating activities of connectors from boards. During gold extraction from connectors, $5.5 \%$ of total gold is lost as scrap metals and $6 \%$ of total gold is lost in gas/liquid form [35]. This study provides an evaluation that gold yield from Chinese informal PCB recycling may be higher than that in Indian case but no recovery rate has been given.

By interview, the amount of recovered gold is about 2.5-5.5 g per $\mathrm{kg}$ of gold fingers and CPUs depending on their quality. To calculate chemical used for acid neutralizing and precipitating step, gold content in treated gold "fingers" is needed. To do so, the overall gold recovery rate is assumed at $25 \%$ (or $20.5 \mathrm{~g}$ based on gold content in PCBs is $82 \mathrm{ppm}$ [32]) and each $\mathrm{kg}$ of high gold-contained parts treated can achieve around $5.0 \mathrm{~g}$ of pure gold. The overall recovery rate is considered a rough assumption. Thus, the amount of high gold-contained parts is about $4.1 \mathrm{~kg}$. Due to no gold concentration data analysis in the input, the gold content is calculated theoretically under some assumptions: high goldcontained materials are gold "fingers", total amount of gold is $82 \mathrm{~g}$ per $\mathrm{t}$ of PCBs [30], PCBs are made from flame retardant grade 4 (FR4) - a woven glass fabric with epoxy resin with the density of $1.85 \mathrm{~g} / \mathrm{cm}^{3}$, gold-plated layer thickness is at $30 \mu \mathrm{in}$ [36], thickness of PCBs is at $1.6 \mathrm{~mm}$ [37], width of gold-plated connectors is $6 \mathrm{~mm}$, gold-plated connectors cover both sides of boards, they are under a "good" cut, and density of gold is $19.32 \mathrm{~g} / \mathrm{cm}^{3}$. Thus, the gold content in $4.1 \mathrm{~kg}$ of gold "fingers" is calculated as $24.5 \mathrm{~g}$.

The informal practices of gold recovering and purifying are varied in quantity of chemical using (ratio of $\mathrm{HCl}$ and $\mathrm{H}_{2} \mathrm{O}_{2}$ can be $1: 1,2: 1-3: 1$ ), reaction time and temperature. In fact, recyclers observe the appearance of bubbles released, color of solution, gold-plated connectors stuck 
Fig. 3 Flowchart of copper recovery from PCBs under mechanical process

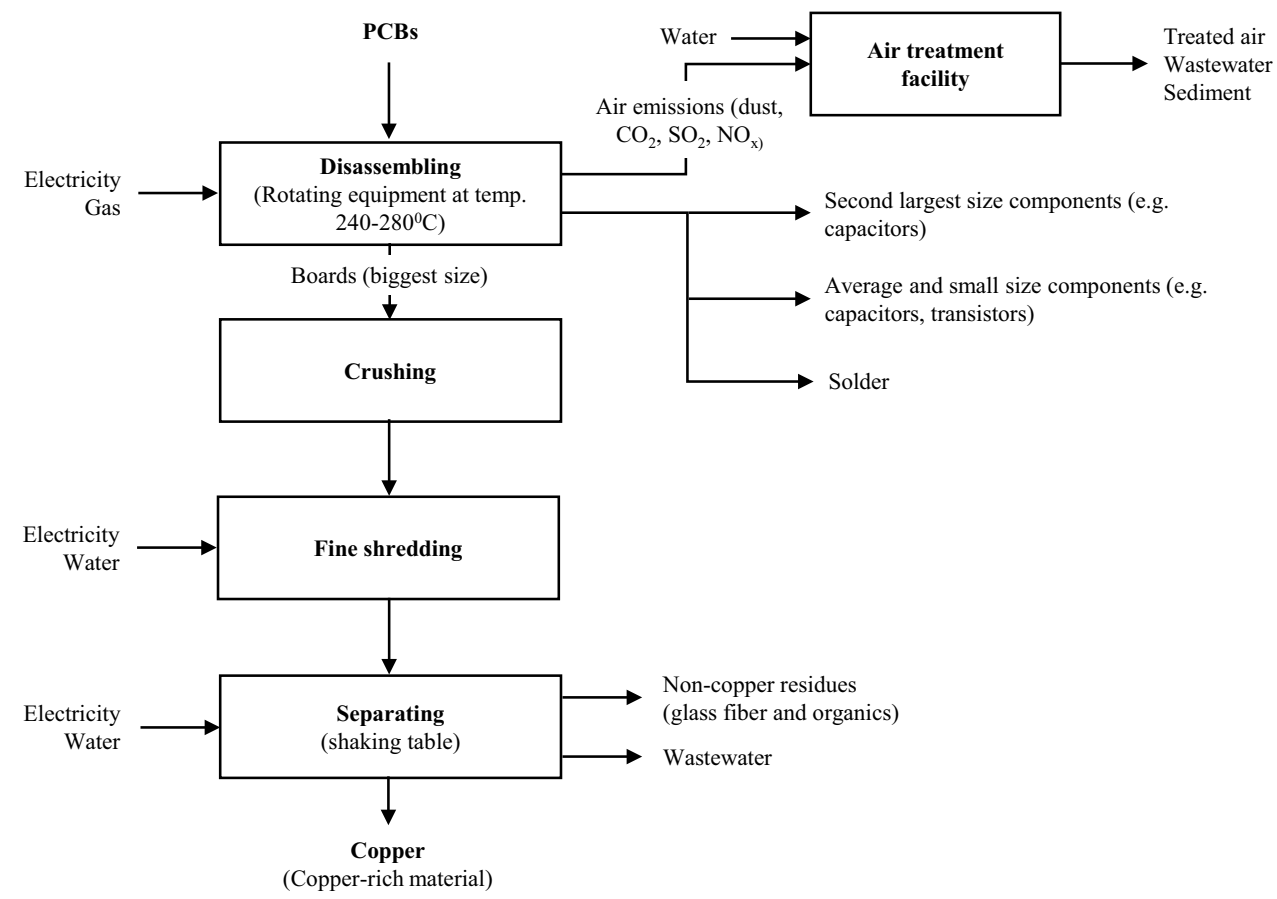

on the "fingers" to adjust the volume of chemicals or reuse them for another batch or re-leach gold "fingers" with fresh chemical solution. No real data on chemical consumption as well as no air emission (release of acid fume, $\mathrm{NO}_{2}, \mathrm{Cl}_{2}$ ) have been obtained. The volume of chemicals used to calculate has been collected from the same practices found on Youtube from some recyclers [38-41] and verified with the $\mathrm{HCl}: \mathrm{H}_{2} \mathrm{O}_{2}$ ratio is at $1: 1$.

Reactions happen during gold recovery and purification, as follows:

Dissolving of copper in mixture of $\mathrm{HCl}$ and $\mathrm{H}_{2} \mathrm{O}_{2}$ :

$$
\mathrm{Cu}+\mathrm{H}_{2} \mathrm{O}_{2}+2 \mathrm{HCl}=\mathrm{CuCl}_{2}+2 \mathrm{H}_{2} \mathrm{O}
$$

Dissolving of gold in aqua regia [42]: $2 \mathrm{HNO}_{3}+6 \mathrm{HCl}$

$$
\rightarrow 2 \mathrm{NO}+2 \mathrm{H}_{2} \mathrm{O}+3 \mathrm{Cl}_{2}
$$

$2 \mathrm{Au}+3 \mathrm{HNO}_{3}+9 \mathrm{HCl} \rightarrow 2 \mathrm{AuCl}_{3}+3 \mathrm{NOCl}+6 \mathrm{H}_{2} \mathrm{O}$

$\mathrm{HNO}_{3}+3 \mathrm{HCl} \rightarrow \mathrm{Cl}_{2}+\mathrm{NOCl}+2 \mathrm{H}_{2} \mathrm{O}$

For calculation: $2 \mathrm{Au}+6 \mathrm{HNO}_{3}+18 \mathrm{HCl} \rightarrow 2 \mathrm{AuCl}_{3}$

$$
+2 \mathrm{NO}+4 \mathrm{Cl}_{2}+4 \mathrm{NOCl}+12 \mathrm{H}_{2} \mathrm{O}
$$

$2 \mathrm{NO}+\mathrm{O}_{2}=2 \mathrm{NO}_{2}$

Adding urea to the filtered solution: $\left(\mathrm{NH}_{2}\right)_{2} \mathrm{CO}+2 \mathrm{HCl}$

$$
+\mathrm{H}_{2} \mathrm{O}=2 \mathrm{NH}_{4} \mathrm{Cl}+\mathrm{CO}_{2}
$$

$$
\left(\mathrm{NH}_{2}\right)_{2} \mathrm{CO}+\mathrm{HNO}_{3}=\left(\mathrm{NH}_{2}\right)_{2} \mathrm{COHNO}_{3}
$$

Adding sodium bisulfite to the solution: $2 \mathrm{AuCl}_{3}$

$$
\begin{aligned}
& +3 \mathrm{NaHSO}_{3}+3 \mathrm{H}_{2} \mathrm{O}=2 \mathrm{Au}+3 \mathrm{NaHSO}_{4}+6 \mathrm{HCl} \\
& \mathrm{NaHSO}_{3}+\mathrm{HCl}=\mathrm{NaCl}+\mathrm{H}_{2} \mathrm{O}+\mathrm{SO}_{2}
\end{aligned}
$$

The input and output data for gold recovery from PCBs are present in Table 4.

Besides the extracted gold, this process results in some critical issues from (1) air emission in gold leaching includes several toxic gases $\left(\mathrm{NO}_{2}, \mathrm{Cl}_{2}, \mathrm{NOCl}, \mathrm{SO}_{2}\right.$ and acid fume). The presence of those gases required good air ventilation and air treatment and protective gears for operators; (2) wastewater consists of hazardous substances (acid, heavy metals). Thus, it needs to be paid attention and treated properly using chemical treatment (for example, using Calcium hydroxide to neutralize residue acids and form precipitation from presence of ion metals); and (3) glass fiber and organics from boards as solid waste stream contains flame retardants.

For whole PCBs, only one workshop in Hung Yen province has a processing line. The detailed process had been described in the study of Tran and Salhofer [5] and illustrated in Fig. 3, in which PCBs are treated under horizontal rotating equipment at temperature from 240 to $280{ }^{\circ} \mathrm{C}$ to separate solder, transistors, capacitors and circuit boards. Within this range of temperature, only solders are melt while the rests are restricted weight loss [43]. The outputs per tonne of treated PCBs from this process consist of approximately $44 \mathrm{~kg}$ of solder metals, $176 \mathrm{~kg}$ of average and small components (e.g., chips, transistors, small capacitors), $100 \mathrm{~kg}$ of the second largest size components 
Table 4 Consumption data and outputs from treatment of $1000 \mathrm{~kg}$ PCBs under current technologies

\begin{tabular}{|c|c|c|c|}
\hline \multicolumn{4}{|l|}{ Gold recovery } \\
\hline Inputs & Unit & Quantity & Note \\
\hline Gold fingers and chips & $\mathrm{kg}$ & 4.100 & $\begin{array}{l}\text { Calculated with the assumption of overall recovery rate is at } \\
25 \% \text { and } 5.0 \text { g of gold can be extract from each kg of high- } \\
\text { gold-contained parts }\end{array}$ \\
\hline Hydrogen peroxide $3 \%(d=1 \mathrm{~g} / \mathrm{ml})$ & $\mathrm{kg}$ & 27.333 & \\
\hline Hydrochloric acid $(\mathrm{HCl}) 20 \%(d=1.098 \mathrm{~g} / \mathrm{ml})$ & $\mathrm{kg}$ & 29.520 & \\
\hline Hydrochloric acid $(\mathrm{HCl} 36 \%)$ for aqua regia $(d=1.789 \mathrm{~g} / \mathrm{ml})$ & $\mathrm{kg}$ & 1.375 & \\
\hline Nitric acid $\left(\mathrm{HNO}_{3} 68 \%\right)$ for Aqua regia $(d=1.405 \mathrm{~g} / \mathrm{ml})$ & $\mathrm{kg}$ & 0.360 & \\
\hline Water for washing & $\mathrm{kg}$ & 20.000 & \\
\hline Urea & $\mathrm{kg}$ & 0.584 & Calculated from reaction (6) and (6*) \\
\hline$\underline{\text { Sodium Bisulfite }}$ & $\mathrm{kg}$ & 0.058 & Calculated from reaction (7) and ( $7 *)$ \\
\hline Outputs & Unit & Quantity & Note \\
\hline Gold & $\mathrm{kg}$ & 0.0205 & \\
\hline Wastewater & $\mathrm{kg}$ & 80.210 & $\begin{array}{l}\text { Contains residue acid, salt solution of metals }\left(\mathrm{e} . \mathrm{g} . \mathrm{Au}^{3+}, \mathrm{Cu}^{2+}\right) \\
\text { and is hazardous waste }\end{array}$ \\
\hline Solid waste & $\mathrm{kg}$ & 3.034 & \\
\hline Total air emission & $\mathrm{kg}$ & 0.066 & $\begin{array}{l}\text { Summarized from } \mathrm{NO}_{2}, \mathrm{Cl}_{2}, \mathrm{NOCl}, \mathrm{CO}_{2} \text { and } \mathrm{SO}_{2} \text { emission } \\
\text { calculated from reaction (5), (5*), (6) and (7) (the acid fume } \\
\text { is unquantifiable) }\end{array}$ \\
\hline $\mathrm{NO}_{2}$ & $\mathrm{~kg}$ & 0.006 & Calculated from reaction (5) and $\left(5^{*}\right)$ \\
\hline $\mathrm{Cl}_{2}$ & $\mathrm{~kg}$ & 0.018 & Calculated from reaction (5) \\
\hline $\mathrm{NOCl}$ & $\mathrm{kg}$ & 0.016 & Calculated from reaction (5) \\
\hline $\mathrm{CO}_{2}$ & $\mathrm{~kg}$ & 0.003 & Calculated from reaction (6) \\
\hline $\mathrm{SO}_{2}$ & $\mathrm{~kg}$ & 0.024 & Calculated from reaction (7) \\
\hline
\end{tabular}

Copper recovery

\begin{tabular}{|c|c|c|c|}
\hline Inputs & Unit & Quantity & Note \\
\hline PCBs & $\mathrm{kg}$ & 995.900 & $\begin{array}{l}\text { High-gold-contained parts have been separated for gold } \\
\text { recovery }\end{array}$ \\
\hline Water & $\mathrm{kg}$ & 5000.000 & $\begin{array}{l}\text { Water consumption is estimated based on electric pump power } \\
(0.37 \mathrm{~kW}) \text { and its operational time }(8 \mathrm{~h} \text { per day })\end{array}$ \\
\hline \multicolumn{4}{|l|}{ Energy } \\
\hline LPG & MJ & 600.030 & \\
\hline Electricity & $\mathrm{kWh}$ & 165.983 & \\
\hline Outputs & Unit & Quantity & Note \\
\hline Copper rich material & $\mathrm{kg}$ & 284.345 & $\begin{array}{l}\text { Mixture of copper and non-copper materials is at the amount } \\
\text { of about } 42 \mathrm{wt} \% \text { of total shredded input and overall cop- } \\
\text { per recovery rate is assumed at } 95 \mathrm{wt} \% \text {. Copper content is } \\
\text { roundly } 241.32 \mathrm{~kg}\end{array}$ \\
\hline Solders & $\mathrm{kg}$ & 44.019 & Collected and sold \\
\hline Transistors, small capacitors & $\mathrm{kg}$ & 175.278 & Average and small size components. Exported \\
\hline Capacitors and large size components & $\mathrm{kg}$ & 99.590 & Second large size components. Exported \\
\hline Wastewater & $\mathrm{kg}$ & $5,000.000$ & $\begin{array}{l}\text { Water can be recycled after treatment. As if, wastewater can be } \\
\text { reduced to } 1000 \mathrm{~kg}\end{array}$ \\
\hline Solid waste & $\mathrm{kg}$ & 392.667 & Glass fiber and organics, to be landfilled \\
\hline Equivalent $\mathrm{CO}_{2}$ air emission & $\mathrm{kg}$ & 114.103 & Calculated from data provided in Table 3 \\
\hline
\end{tabular}


(e.g., capacitors) and the rest is the largest parts: boards (after removal of components) at the amount of $680 \mathrm{~kg}$. Solder metals are collected for sale. The separated electronic components are collected, shredded (if needed) for exporting. Only the boards are treated at this workshop by mechanical treatment (shredding then separating on shaking table with water flow (Fig. 3) to recover copper. The recycling is done in batch. Each batch, around $500 \mathrm{~kg}$ of PCBs is treated. The collected outputs contain copper-rich material (copper mixed with small amount of glass fibers and organics) at the proportion of approximately $42 \mathrm{wt} \%$ of input PCBs (interview data) and the rest is glass fibers and organics which is collected for landfilling. The copper content in the output can be calculated from the copper recovery rate. This recovery rate is assumed at $95 \mathrm{wt} \%$ based on the same technology from Mt. Baker Mining and Metals (copper recovery rate is higher than 95\%) [44].

From Fig. 2 and Table 4, the PCB treatment for copper extraction includes waste flows: (1) air emission containing $\mathrm{NO}_{x}, \mathrm{SO}_{2}$ from gas combustion which is collected by a sucking fan and released into environment through a chimney; (2) wastewater from process water using during shredding and separating which is collected at a sedimentation tank then discharged; and (3) solid waste which are glass fiber and organics with flame retardants from boards.

As observed from Table 4 for gold recovery, the appearance of toxic gases poses health problem to workers and suggests that protective equipment (mask) needs to be used by workers, a ventilation and air treatment system should be considered. The wastewater stream in which contains not only residue chemicals (hydrochloric acid and hydro peroxide) but also copper $\left(\mathrm{Cu}^{2+}\right)$ at the amount of $1.05 \mathrm{~kg}$ by dissolving $4.1 \mathrm{~kg}$ of high gold content pieces from $1 \mathrm{t}$ of treated PCBs has a high potential for recovery and a treatment system needs to build. For copper recovery process, water using can be recycled but it is needed to invest for wastewater treatment facility (additional filtration step).

Selected BAT Using copper smelters and integrated smelters-refineries is considered as BAT for PCB treatment for copper and other precious metal recovery [45]. The most modern technologies can be found in Europe at Umicore (Hoboken, Belgium), Boliden (Rönnskär, Sweden) or Aurubis (formerly Norddeutsche Affinerie in Hamburg, Germany) [24]. Detailed treatment processes have been described by Isaksson and Lehner [46] for Boliden in Rönnskär and Hagelüken [47, 48] for Umicore in Hobroken. In this study, selected BAT is the metallurgical process applied in Umicore. Under Umicore's technology, the main processes include IsaSmelt smelting, copper leaching and electrowinning, and precious metal refinery [49]. Recovered metals consist of $\mathrm{Au}, \mathrm{Ag}, \mathrm{Pt}, \mathrm{Pd}$, $\mathrm{Rh}, \mathrm{Ir}, \mathrm{Ru}$ (precious metals), $\mathrm{Pb}, \mathrm{Cu}, \mathrm{Ni}, \mathrm{Sb}, \mathrm{Sn}, \mathrm{Bi}, \mathrm{Se}$,
In, Te, As (base and special metals) [47, 48]. The metal recovery rate is above $95 \%[48,50]$. Plastic and organic fraction from feed materials is used as a reducing agent and fuel substitute. The energy content exceeds energy demand for smelting and refining [48]. Other by-products of the plants are sulfuric acid (from off-gas purification) and slag (containing aluminum and iron oxides) that are used as construction material and in the concrete industry. Off-gas emission and wastewater are treated under highly efficient treatment systems to "comply with the strictest environment standards" [50]. The off-gas treatment process installed at IsaSmelt furnace can be seen in the study of Hagelüken [47]. The outputs from treatment of $1 \mathrm{t}$ PCBs under this technology is provided in Table 5 with assumption that the recovery rate of metals is at $95 \%$. Energy consumption is marked with minus (-) as the recycling and refining process produce energy. Other emission load can be referred at Umicore Environmental statements [51], such as $14.544 \mathrm{t}$ of metal emission to air; $1,19 \mathrm{t}$ of $\mathrm{SO}_{x}$ emission; $45 \mathrm{t}$ of $\mathrm{NO}_{x}$ emission; 714,225 $\mathrm{t}$ of equivalent $\mathrm{CO}_{2}$ emission in 2015.

Table 5 shows a large gap between recovered metals between 2 scenarios. Together with Table 4, it is clear that Umicore has treated PCBs under advanced technology: recovering and refining metals at high rate and quality, more recovered metals, no energy needed, and advanced waste treatment technology. The recycling processes under current technologies generate approximately $395.701 \mathrm{~kg}$ of solid waste; $5000 \mathrm{~kg}$ of wastewater from copper recovery with high recycling potential; $80.210 \mathrm{~kg}$ of wastewater containing hazardous substances (acid, heavy metal) with copper recover potential and required treatment before discharging to environment; and $114.103 \mathrm{~kg}$ of equivalent $\mathrm{CO}_{2}$ emission from electricity and LPG consumption. The exported components to China are considered as the material loss under current context.

\section{Ferrous metal recycling}

Current technology In Vietnam, the most common technologies for steel production are electric arc furnace (EAF) (for large manufacturer), induction furnace (IF) (for small and medium sized enterprises) and basic oxygen furnace (BOF). 95\% of big manufacturers in Vietnam are using EAF [10]. Since 2009, many large steel manufacturers in Vietnam installed and used big capacity IF smelters (5-50 t) and their designed capacity gains up to $20 \%$ total steel-making capacity of the nation [52]. At craft villages, such as Da Hoi (Bac Ninh province), Tong Xa (Nam Dinh province), ferrous scraps are recycled under medium-frequency IF technology with a capacity of $0.5-1 \mathrm{t}$ per batch. Ferrous recycling villages contribute a large amount of steel products to domestic market. For example, smelters in Da Hoi village 
Table 5 The input and output data from treatment of $1000 \mathrm{~kg}$ PCBs between current technology and selected BAT

\begin{tabular}{|c|c|c|c|c|c|}
\hline \multicolumn{6}{|c|}{ Per $1000 \mathrm{~kg}$ of PCBs from waste desktop PC } \\
\hline & \multirow[t]{2}{*}{ Unit } & \multicolumn{2}{|c|}{ Current operation } & \multicolumn{2}{|c|}{ Selected BAT } \\
\hline & & Quantity & Note & Quantity & Note \\
\hline \multicolumn{6}{|l|}{ Inputs } \\
\hline PCBs & $\mathrm{kg}$ & 1000.000 & & 1000.000 & \\
\hline Chemicals & $\mathrm{kg}$ & 59.231 & & & \\
\hline Water & $\mathrm{kg}$ & 5020.000 & & & \\
\hline Energy & & & & - & $\begin{array}{l}\text { The energy content exceeds energy } \\
\text { demand for smelting and refining }\end{array}$ \\
\hline Electricity & $\mathrm{kWh}$ & 165.983 & & & \\
\hline LPG & MJ & 600.030 & & & \\
\hline \multicolumn{6}{|l|}{ Recovered metal outputs } \\
\hline Gold & & 0.0205 & & 0.078 & \\
\hline Copper rich material & $\mathrm{kg}$ & 284.345 & $\begin{array}{l}\text { In which, the copper content is } \\
241.257 \mathrm{~kg}\end{array}$ & 242.250 & \\
\hline Solder metals & $\mathrm{kg}$ & 44.019 & & & \\
\hline Other metals & $\mathrm{kg}$ & - & & 62.316 & $\begin{array}{l}\text { Other metals include precious metals } \\
(\mathrm{Au}, \mathrm{Ag}, \mathrm{Pd}) \text {, base and special met- } \\
\text { als }(\mathrm{Ni}, \mathrm{Sn}, \mathrm{Sb})\end{array}$ \\
\hline Total recovered metals & $\mathrm{kg}$ & 285.299 & $\begin{array}{l}\text { Without non-copper materials in } \\
\text { the mixture output from copper } \\
\text { recovery }(43.088 \mathrm{~kg})\end{array}$ & 304.654 & \\
\hline \multicolumn{6}{|l|}{ Other fractions/streams } \\
\hline Exported components & $\mathrm{kg}$ & 274.868 & & - & \\
\hline $\begin{array}{l}\text { Burned fraction for energy recov- } \\
\text { ery }\end{array}$ & $\mathrm{kg}$ & - & & 512.400 & \\
\hline Solid waste & $\mathrm{kg}$ & 395.701 & & - & \\
\hline $\begin{array}{l}\text { Metal in slag and other waste } \\
\text { streams }\end{array}$ & $\mathrm{kg}$ & - & & 182.945 & $\begin{array}{l}\text { Metal in slag is used as construc- } \\
\text { tion material and in the concrete } \\
\text { industry }\end{array}$ \\
\hline $\begin{array}{l}\text { Copper content in wastewater from } \\
\text { gold recovery }\end{array}$ & $\mathrm{kg}$ & 1.05 & Copper salt solution & - & \\
\hline
\end{tabular}

produce $12,000-15,000 \mathrm{t}$ of steel billets; $450,000-500,000 \mathrm{t}$ of steel sheets per year [53].

Producing $1 \mathrm{t}$ of final products (steel billets) needs to consume 1.05-1.08 [52] or 1.25-1.3 [54-57] t scraps, $750-1300 \mathrm{kWh}$ of electricity [54-58] and 0.2-0.3 t coal for annealing as seen at several smelters [19]. Besides, flux (lime/dolomite) (10-15 kg per t of product) and auxiliary (7-10 kg per $\mathrm{t}$ of product) (interview data) are added to melting process. Water is used for cooling purpose and can be recycled after cooling. Volume of wastewater without recycling is in the range of $5-7 \mathrm{~m}^{3}$ per $\mathrm{t}$ of final product $[54,55$, 57]. Waste streams consist of solid waste (slag is $20-25 \mathrm{~kg}$ (interview data) or $45 \mathrm{~kg}$ [55] per tonne of steel billets and it depends on scrap quality; impurities (soil, paper, plastic) are approximately $12.5-14 \mathrm{~kg}$ per tonne of steel billets [59]; and metal granule from scattering and surface cutting is around $13 \mathrm{~kg}$ per tonne of steel billets). Molds for casting are made from clay or sand, but the most popular ones are from iron. If molds are metallic type, they are reused for other batches. If molds are made of sand, sand can be recycled partly. Metallic molds, most popularity is iron molds, are now used very common to produce steel billets. Sand molds are used to cast parts of mechanical equipment. In this case, molds need to be prepared before casting. Materials for sand molds making mainly consist of sand, clay, water and coal powder. The amount of sand can be recycled after mold dismantling is about $80 \mathrm{wt} \%$ [54]. Detailed data for steel recycling under IF technology are provided in Table 6.

The recycling process selected in this study is summarized in Fig. 4. Firstly, steel scraps are classified. At this step, impurities (soil, plastics, etc.) are sorted out and collected for dumping or landfilling and other non-ferrous metals are collected for sale. If the width of scraps is exceeded $20 \mathrm{~cm}$, they need to be cut into smaller pieces. Then, the prepared scraps are transported to the furnace, charged into it and melted. Metal slag is removed during melting periodically. 
Table 6 The input and output data from recycling of $1000 \mathrm{~kg}$ steel scraps between current technology and selected BAT

\begin{tabular}{|c|c|c|c|c|c|}
\hline \multirow[t]{2}{*}{ Input } & \multirow[t]{2}{*}{ Unit } & \multicolumn{2}{|c|}{ Current technology } & \multicolumn{2}{|c|}{ Selected BAT } \\
\hline & & Quantity & Note & Quantity & Note \\
\hline Steel scraps & $\mathrm{kg}$ & 1000.00 & & 1000.00 & \\
\hline Flux (lime/dolomite) & $\mathrm{kg}$ & 9.26 & & 9.52 & \\
\hline Auxiliary & $\mathrm{kg}$ & 9.26 & FeMn80 and FeSi75 & 6.67 & \\
\hline Refractory-ceramic powder & $\mathrm{kg}$ & 3.70 & & 3.81 & \\
\hline Cooling water & $\mathrm{kg}$ & 6481.48 & Without water recycling & 380.95 & $\begin{array}{l}\text { Added water or lost } \\
\text { water by evapora- } \\
\text { tion }\end{array}$ \\
\hline Electricity & $\mathrm{kWh}$ & 925.93 & & 550.00 & \\
\hline Output & Unit & Quantity & Note & Quantity & Note \\
\hline Product & $\mathrm{kg}$ & 925.93 & & 952.38 & \\
\hline Total solid waste & $\mathrm{kg}$ & 46.76 & & 21.81 & \\
\hline Solid waste-impurities & $\mathrm{kg}$ & 11.57 & & - & \\
\hline Solid waste—metal slags & $\mathrm{kg}$ & 23.15 & & 15.00 & \\
\hline $\begin{array}{l}\text { Liquid metal scattered during pouring and metal } \\
\text { residues from steel billets (recyclable) }\end{array}$ & $\mathrm{kg}$ & 12.04 & & - & \\
\hline Refractory waste & $\mathrm{kg}$ & 3.70 & & 3.81 & \\
\hline Dust collected from air treatment facility & $\mathrm{kg}$ & - & & 3.00 & \\
\hline Wastewater & $\mathrm{kg}$ & 4629.63 & & - & \\
\hline Equivalent $\mathrm{CO}_{2}$ emission & $\mathrm{kg}$ & 432.27 & $\begin{array}{l}\text { Calculated from data pro- } \\
\text { vided in Table } 3\end{array}$ & 256.77 & \\
\hline
\end{tabular}

After casting molten iron into iron molds, molds are cooling by natural air. Later, still billets are removed from molds (mold disassembling step) and molds are reused for another batch. At some smelters, steel billets or casted products can be annealed under heat generated from coal combustion.

Ferrous recycling process results in several critical issues. As seen from Fig. 4, air emission flow is the most serious one. Dust generated from cutting step consists of metal dust and ferrous rust. When charging scraps into furnace, especially the cold charge (for example, the first charge of the day) [60], high emission (mainly particles from rust, dust) is released into environment. During melting process, gaseous emission is formed which may contain metal and metal oxides, organic compounds from the incomplete combustion of impurities and coating layer of scraps, and other gases such as $\mathrm{CO}, \mathrm{NO}_{\mathrm{x}}$. During casting step, metal and metal oxide particles are generated; other volatile compounds may emit from burning of additives (e.g., coal powder, sand). If coal is used for annealing, its combustion generates dust, $\mathrm{SO}_{2}$, $\mathrm{NO}_{x}$. Moreover, dust can be released during removal of steel billets out from molds. Thus, it is considered that gaseous emission release is general issue in all steps of ferrous recycling. However, studies focusing on air emission from ferrous recycling workshops at craft villages are missing leading to impossibility to quantify air pollutants.

Besides air waste flow, solid waste is considered as another issue with the presence of impurities from scraps,

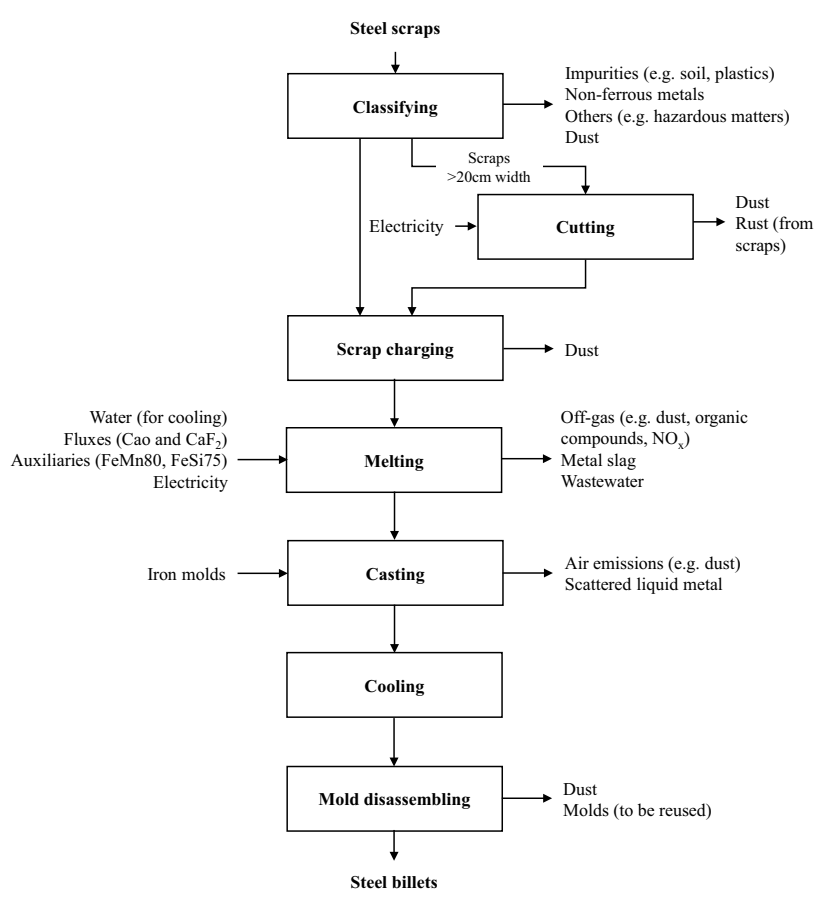

Fig. 4 Flowchart of ferrous metal recycling at craft villages

slag waste, and refractory waste generated from periodically repairing/preparing furnace lining layer. Only solid metal formed from liquid metal scattered on the floor and metal 
residues from steel billets can be recycled directly. Slag waste is noticeable by high chemical complex as it contains various contaminants such as metal oxides, melted refractories and other metals (e.g., lead, cadmium, chromium) from steel or non-ferrous metal components.

Selected BAT In this scenario, each smelter invests for better technology matching with their own production capacity to improve product quality while increasing operating efficiency. Thus, the selected BAT to compare with current technology is also IF technology. Compared to EAF technology, IF technology shows some advantages which are suitable for smelters at craft villages, such as lower environmental burden generated from furnaces and needs little maintenance [20] while the electricity price per kWh in Vietnam is relatively lower than that in other Asian countries [52]. The furnace capacity is in very wide range, from 0.01 to $30 \mathrm{t}$ per batch [20]. To produce steel billets (as final product), steel scraps are needed, together with carburizing agents or flux, water for cooling and electricity $(550-650 \mathrm{kWh} / \mathrm{t}$ of metal charge can be achieved) [20]. The best achieved energy consumption is $538.1 \mathrm{kWh}$ per $\mathrm{t}$ of crude steel [11]. The emission from this technology has slag (10-20 kg per $\mathrm{t}$ of metal charge) and dust (0.04-3 kg per t of metal charge) [20]. Cooling water can be recycled about $90 \%$ [61] with the overall water consumption is ranging from 1.6 to $3.3 \mathrm{~m}^{3}$ per $t$ of steel [61]. The water is lost by evaporation.

Detailed inputs and outputs of selected BAT for steel recycling are presented in Table 8 , together with the current technology.

As seen from Table 6, the most significant improvement coming from selected BAT is the reduction of electricity consumption (1.7 times). Moreover, air treatment facility has been installed and cooling water is recycled. It is suggested that new smelter with higher energy efficiency should be invested. Better scrap quality management contributes to the reduce of solid waste, such as sorting, applying "first in, first out" principle in which the scrap should be melted in the same chronological order with the time when it is bought to prevent loss by oxidation. Water cooling tower might be used for water recycling. Air emission collection (e.g., suction hood above smelter) and treatment system also need to consider.

\section{Plastic recycling}

Current technology Plastic fractions from the dismantling of e-waste contain many types of plastics (15 or more) [62] in which the highest amounts are accounted for acrylonitrile butadiene styrene (ABS), polystyrene (PS), polypropylene (PP) at $70-80 \%$ of the total [45, 62]. Plastic separating and sorting are a big challenge as the complexity of different types of electronic equipment from different producers or different product series is high [63]. Thus, plastics as output from the shredding process are a mixture of many types of plastics with look-alike colors. After manual separating and sorting, plastics are shredded under wet or dry technology. Electricity needs for this step is about $17 \mathrm{kWh} / \mathrm{t}$. Shredded plastics are mainly recycled by two technologies: (1) extrusion and (2) injection molding. Both technologies are suitable for ABS recycling [64]. At craft villages (such as Minh Khai, Trieu Khuc in Hanoi, Phan Boi in Hung Yen province) and other small and medium sized enterprises in Vietnam, the extrusion technology is used more commonly to produce secondary plastic pellets or recycled products. Depending on the types of plastics, the products are varied (such as bags, weaving fabric, thread, containers, chairs, basins, etc.).

The plastic recycling from shredded plastics consists of 2 main processes: (1) making secondary pellets and (2) making products from a mixture of primary and secondary pellets. In this study, the first process: making secondary plastic pellets is investigated as shown in Fig. 5. In which, clean and shredded plastics are mixed by putting them in a cone-shape funnel, then fed into the extruder with heat generated from electricity. After extruding, plastic strands are cooled in water and cut into pellets (cold cut).

Data collected from SMEs and workshops at craft villages in Vietnam show that the capacity for shredder is 200-300 kg per h [19]. Producing each tonne of secondary plastic pellets needs $1.03-1.07 \mathrm{t}$ of plastic scraps [65, 66], approximately $350-400 \mathrm{kWh}$ of electricity for $100-250 \mathrm{~kg}$ of secondary plastic pellets per hour [65, 67]. With considering to production size of recyclers at craft villages for plastic pellets from e-waste source, the selected product capacity is approximately $100 \mathrm{~kg} / \mathrm{h}$ and the electricity

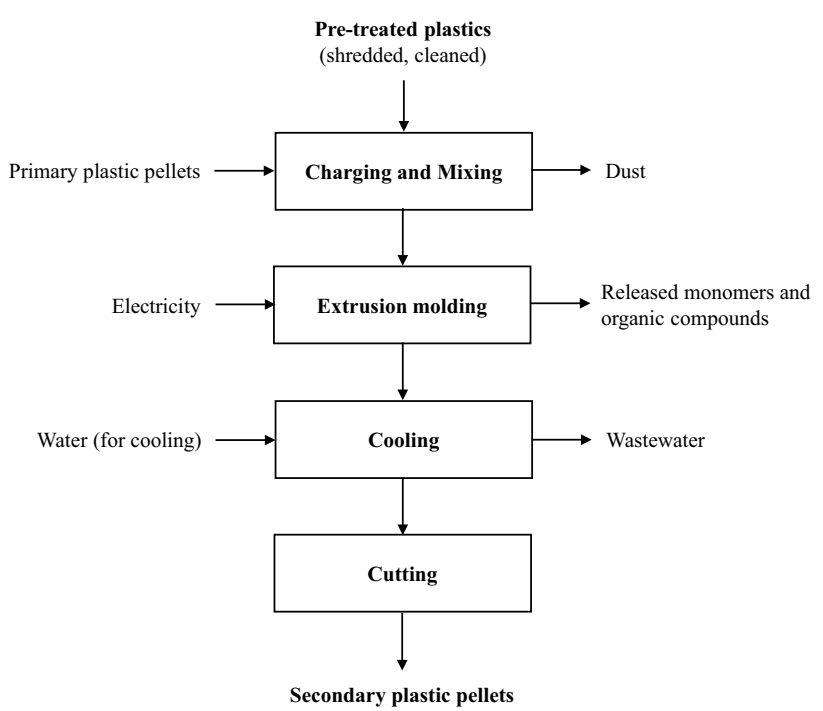

Fig. 5 Flowchart of making secondary plastic pellets at craft villages 
consumption is $0.35 \mathrm{kWh} / \mathrm{kg}$. Water for cooling purpose without recycling is about $21.7 \mathrm{~m}^{3}$ as observed from a small-sized company [66] up to $51 \mathrm{~m}^{3}$ as provided in the study of Dang [19] per tonne of products.

Out of secondary plastic pellets, plastic recycling includes several waste flows. Air emission is the most critical concern during charging of shredded plastics into cone-shape funnel as dust may be formed and, especially during extruding of plastic as air pollutants (e.g., monomers, or other organic compounds) are generated. It is possible that acrylonitrile monomer is released into the air resulting from thermal degradation of ABS while acrylonitrile is dangerous to exposed workers' health (for example, possible carcinogen to humans, increased lymphocyte counts, severe liver damage, lung cancer, chromosomal aberrations) [68]. In case of melting of polystyrene, released styrene can cause cancer to workers, or act as an endocrine disrupter [68].

This recycling process generates wastewater from cooling of plastic wires that can be recycled and solid waste which includes mainly impurities such as soil, paper is in the range of $8-11 \mathrm{~kg} / \mathrm{t} \mathrm{[59]} \mathrm{and} \mathrm{plastic} \mathrm{pellets} \mathrm{scattered} \mathrm{on} \mathrm{the} \mathrm{floor}$ which are collected together with products about $37-40 \mathrm{~kg} / \mathrm{t}$ $[66,69])$.

Selected BAT As stated in the previous section, the selected BAT is the same with the technology in the current scenario: extrusion technology. The consumed plastic scrap is assumed at $1.03 \mathrm{t}$ per $\mathrm{t}$ of secondary plastic pallets. The energy consumption and volume of cooling water are considerably variable as they are affected by process types, production mix, etc. [70]. Energy consumption is depended on process load [71] or production capacity $(\mathrm{kg} / \mathrm{h})$. Data for energy and water consumption are obtained from the manufacturers' technical data sheets (e.g., BKG). Energy consumption per kg of pellet output is approximately $0.2 \mathrm{kWh}$ for each $\mathrm{kg}$ of plastic pellets at capacity of $100 \mathrm{~kg}$ per h [67]. Crosschecked with the energy consumption for extrusion process with the same capacity, the energy consumption is calculated as $0.18 \mathrm{kWh}$ [71]; the electricity consumption proposed for calculation in BAT is $0.2 \mathrm{kWh}$ per kg of plastic pellets. In selected BAT/BEP, water using for cooling purpose is recycled and only water is loosed by evaporation. Thus, there is no wastewater. The water flow for output capacity in the range $2-500 \mathrm{~kg} / \mathrm{h}$ is $15 \mathrm{~m}^{3} / \mathrm{h}$ (maximum flow) [72]. Water needed is roundly $30 \mathrm{~m}^{3}$ per $\mathrm{t}$ of products. The solid waste stream counts for impurities at the amount of $11 \mathrm{~kg}$ per $\mathrm{t}$ of products $(8-11 \mathrm{~kg} / \mathrm{t}$ [59]).

Detailed inputs and outputs from plastic recycling under selected BAT in comparison with current scenario are presented in Table 7.

Table 7 shows the saving potential between 2 technologies in which the electricity consumption in the first scenario is higher than that for the second at least 1.7 times. It leads to the reduction of equivalent $\mathrm{CO}_{2}$ emission. To improve energy efficiency, extruders with higher energy efficiency can be invested or better process control should be implemented (e.g., running at its most efficient speed, controlling electric motor to match the torque). It is necessary to reduce water consumption by recycling cooling water, so it contributes to not only water saving, but chemicals and energy for water treatment and pumping. Better ventilation system can help to reduce significantly concentration of pollutants.

Table 7 The input and output data from recycling of $1000 \mathrm{~kg}$ plastic scraps between current technology and selected BAT

\begin{tabular}{|c|c|c|c|c|c|}
\hline & \multirow[t]{2}{*}{ Unit } & \multicolumn{2}{|c|}{ Current technology } & \multicolumn{2}{|c|}{ Selected BAT } \\
\hline & & Quantity & Note & Quantity & Note \\
\hline \multicolumn{6}{|l|}{ Input } \\
\hline Plastic scraps & $\mathrm{kg}$ & 1000.00 & & 1000.00 & \\
\hline Cooling water & $\mathrm{kg}$ & $20,280.37$ & & $14,563.11$ & \\
\hline Electricity & $\mathrm{kWh}$ & 327.10 & & 194.17 & \\
\hline \multicolumn{6}{|l|}{ Output } \\
\hline Product & $\mathrm{kg}$ & 934.58 & & 970.87 & \\
\hline Total solid waste & $\mathrm{kg}$ & 47.66 & & 10.68 & \\
\hline Solid waste-impurities & $\mathrm{kg}$ & 10.28 & & 10.68 & \\
\hline $\begin{array}{l}\text { Solid waste—scattered pellets } \\
\text { (recycled) }\end{array}$ & $\mathrm{kg}$ & 37.38 & & - & \\
\hline Wastewater & $\mathrm{kg}$ & $18,411.21$ & Without water recycling & - & $\begin{array}{l}\text { Cooling water is recycled. Water } \\
\text { is lost by evaporation at small } \\
\text { volume }\end{array}$ \\
\hline Air emission (dust, smoke) & $\mathrm{kg}$ & - & & - & \\
\hline Equivalent $\mathrm{CO}_{2}$ emission & $\mathrm{kg}$ & 152.71 & $\begin{array}{l}\text { Calculated from data pro- } \\
\text { vided in Table } 3\end{array}$ & 90.65 & \\
\hline
\end{tabular}


Aluminum recycling

Current technology Aluminum is recycled at craft villages (such as Man Xa village in Bac Ninh province, Binh Yen village, Tong Xa village, Van Chang village in Nam Dinh province) from aluminum scraps (such as aluminum gears and frames, cooler, plates, wires, aluminum cans, old basins and cookware). Some types of scrap are contaminated from coating layers, oil, paint (e.g., cans, machinery parts). Recyclers at craft villages produce a large amount of products. For example, recyclers in Man Xa village produce about 200-250 $t$ of aluminum products per year or in Van Chang village; the total amount of products from aluminum and steel making is roundly $17,000 \mathrm{t}$ per year [53]. The main scrap sources come from aluminum cans, old aluminum basins and cookware, aluminum frames and machinery parts while aluminum scrap from e-waste source is at a small proportion.

The scrap from aluminum cans is normally melted separately from other scrap sources. The other scrap sources may need to cut into smaller pieces and mixed from several types during charging into smelter-small coal furnace. At smelter, aluminum scrap is melted. Metal slag is removed during melting process. Molten aluminum can be processed under two common stages: (1) casting for aluminum ingot products and making products from ingots under mechanical processes or (2) casting for products (cookware, basins, motorcycle parts). In both cases, molds (made of metal, sand or clay) are used. After cooling, molds are dissembling to get ingots or semi-products. Metal molds can be reused for other batches or mold materials can be recycled. If products are made from ingots, aluminum sheets are formed by mechanical steps (rolling, milling, cutting), then hydraulic pressers are used to form semi-products. From semi-products, residues are removed and collected for recycling. If producing cookware, support grips are attached. Then, products are passed through surface treatment (oil removal, water cleaning, Chromic acid treatment) for better appearance (Fig. 6). Normally, all steps are done at the workshop, except for sheet making steps which is mostly outsourcing at few larger workshops. As observed at some aluminum casting craft villages, aluminum in discharged metal slag can be recovered by manually separating/washing in water at ponds, drainage system. Aluminum is then collected and sold to smelters.

Melting of aluminum scrap is in batch operation. Each batch, approximately $200 \mathrm{~kg}$ of scraps is used to produce $170 \mathrm{~kg}$ of aluminum ingots [13] or 1.18-1.25 t scraps and $0.47-0.9 \mathrm{t}$ coal are needed for each tonne of final products (motorcycle parts, cooks) [19, 73, 74]. Additionally, water for cooling is needed at the volume from 13 to $21 \mathrm{~m}^{3}$ per $\mathrm{t}$ of final products $[13,56,73,74]$. This volume of water has high potential to be recycled after cooling.
Besides aluminum ingots, this recycling process creates waste streams which are influenced by types and quality of scraps [21] and comprise air emission, wastewater (cooling water and wastewater from surface treatment) and solid waste. The most critical issue is the dust released into environment from all "dry" steps: classifying, cutting, charging, melting, mold dissembling, sheet making, and residue cutting. Especially, generated dust during charging contains metals, soil and released dust during melting consists of metals and metal oxides from the presence of other metals, organic contaminants from incomplete combustion of organic matters, other gaseous pollutants (e.g., $\mathrm{CO}, \mathrm{SO}_{2}$, $\mathrm{NO}_{x}$ ) from coal burning. The most common practice to cope with the air emission issue is to dilute pollutant concentration by constructing some high chimneys. There is no update study available to identify the concentration of metals and organic compounds in air from those recycling villages. But, statistical data on disease of residents living within the recycling villages are accessible. Taken Man Xa village as one example, approximately $50.2 \%$ of Man Xa residents have related respiratory diseases (pharyngitis, bronchitis, pneumonia) [53].

For wastewater, the main source of wastewater is from cooling water and surface treatment. Moreover, aluminum recycling villages are facing with the problem of wastewater containing toxic chemicals from surface treatment (e.g., metal, chromic acid, sulfuric acid or sodium hydroxide). Aluminum recovery activity from metal slag by washing/ separating it in water from ponds or drainage channels, together with metal slag gathered at unplanned open dumping sites may poison water bodies. The study of Nguyen [53] shows that the concentration of zin, chromium, nickel, lead in wastewater from two recycling workshops in Man Xa village, is higher than Vietnamese National Technical Regulation on Environment for discharged wastewater-QCVN 40:2011/BTNMT (the values in brackets are alloweddischarge pollutant concentration in wastewater regulated by QCVN 40:2011/BTNMT) from 3.18 to 4.72 (3 mg/l), 2.02-3.27 (1 mg/l), 2.95-4.49 (0.5 mg/l), 2.68-4.29 times $(0.5 \mathrm{mg} / \mathrm{l})$, respectively (sample taken in 02/2014). Aluminum concentration in wastewater of recycling workshop is from 2106 to $112,045 \mathrm{mg} / \mathrm{l}$ (sample taken in 02/2014).

Solid waste is another serious issue which includes impurities (e.g., soil, rubber, etc. at around $5 \mathrm{wt} \%$ of scraps) that can be sorted out [19], coal slags (15-20 wt\% of consumed coal [57, 75-77]), metal slags (approximately $5-8 \mathrm{wt} \%$ of scraps $[19,78]$ ), dust sedimentation from air emission and small pieces of aluminum or aluminum granulate generated during mechanical processes. Metal slags from aluminum recycling have high potential to be recycled by making other products (by-products) (e.g., aluminum sulfate) as it contains $28-45 \mathrm{wt} \%$ of aluminum [78]. Another source of solid waste is refractory waste 
Fig. 6 Flowchart of aluminum recycling at craft villages

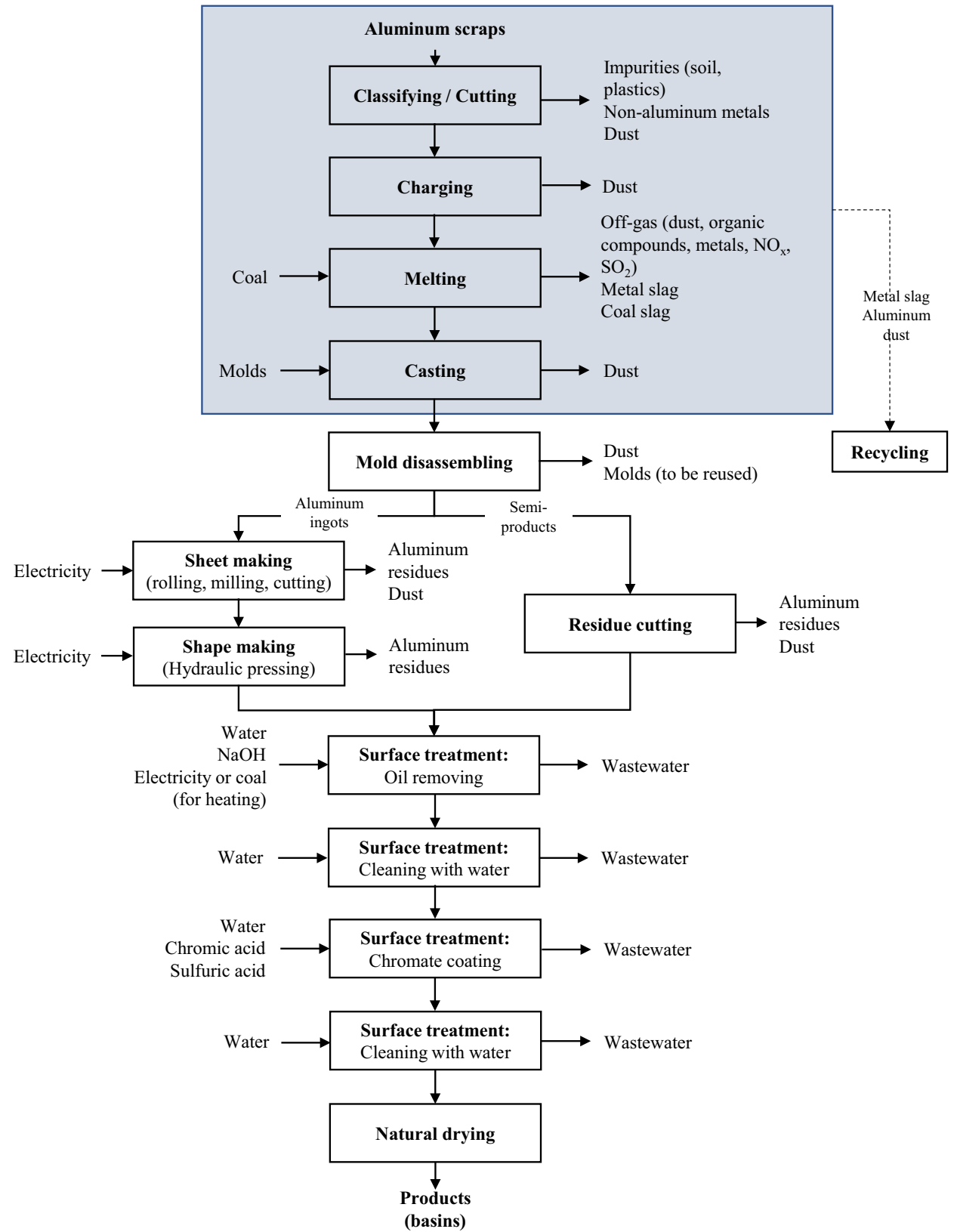

from preparing/preparing of smelters. Currently, solid waste has not treated properly. It ends up in unplanned open dumping sites: gardens, ponds, etc.

In this study, selected current practice for aluminum recycling is that ingots are made, then products (basins) are produced from aluminum ingots. The selection is based on the fact that aluminum ingots are considered as products from recycling business. Detailed inputs and outputs from current recycling technology are presented in Table 8.

Selected BAT With small to medium production capacity and aluminum scrap types at craft villages, the most appro- priate technology selected for secondary aluminum production from various types of scrap is reverberatory furnaces. The preferred fuels are vary (LPG, natural gas, extra-light fuel oil) and optimal energy consumption is in the range from 2.4 to $4.4 \mathrm{MJ}$ per $\mathrm{t}$ of metal [21]. Highly contaminated aluminum scrap can be pretreated by removing oil or other organic compounds before melting stage so air emission from melting step can be reduced. Some pre-treatment technologies (e.g., centrifugation, drying using a rotary dryer) are presented in BAT reference document for non-ferrous metals industries [21]. Data obtained from ecoinvent for "aluminum, secondary, from old scrap, at plant" show to make $1 \mathrm{t}$ of aluminum ingots; $1.03 \mathrm{t}$ scrap is needed [22]. 
Table 8 The input and output data from recycling of $1000 \mathrm{~kg}$ aluminum scraps between current technology and selected BAT

\begin{tabular}{|c|c|c|c|c|c|}
\hline & \multirow[t]{2}{*}{ Unit } & \multicolumn{2}{|c|}{ Current technology } & \multicolumn{2}{|c|}{ Selected BAT } \\
\hline & & Quantity & Note & Quantity & Note \\
\hline \multicolumn{6}{|l|}{ Input } \\
\hline Aluminum scraps & $\mathrm{kg}$ & 1000.00 & & 1000.00 & \\
\hline Water (for cooling) & $\mathrm{kg}$ & $12,378.69$ & & 282.78 & \\
\hline Water (for surface treatment) & $\mathrm{kg}$ & 2063.11 & & 2356.49 & \\
\hline $\mathrm{NaOH}$ & $\mathrm{kg}$ & 8.25 & & 8.95 & \\
\hline $\mathrm{NaNO}_{3}$ & $\mathrm{~kg}$ & 8.25 & & 9.43 & \\
\hline Chromic acid & $\mathrm{kg}$ & 2.06 & & 0.71 & \\
\hline Sulfuric acid & $\mathrm{kg}$ & 0.76 & & 0.87 & \\
\hline Electricity & $\mathrm{kWh}$ & 31.36 & $\begin{array}{l}\text { Electricity consumption for mechanical } \\
\text { processing }\end{array}$ & 36.89 & $\begin{array}{l}\text { Electricity } \\
\text { consumption } \\
\text { for mechanical } \\
\text { processing }\end{array}$ \\
\hline Fuel & MJ & $13,867.10$ & From coal & 4271.84 & $\begin{array}{l}\text { From preferred } \\
\text { fuels (e.g. } \\
\text { natural gas, } \\
\text { LPG, etc.) }\end{array}$ \\
\hline \multicolumn{6}{|l|}{ Output } \\
\hline Products & $\mathrm{kg}$ & 825.25 & & 942.60 & \\
\hline Total solid waste & $\mathrm{kg}$ & 251.46 & & 119.26 & \\
\hline Coal slag & $\mathrm{kg}$ & 99.03 & & - & \\
\hline Metal slags & $\mathrm{kg}$ & 74.27 & $\begin{array}{l}\text { Estimated } 7.5 \text { wt } \% \text { aluminum scraps [19] } \\
\text { and aluminum content is from } 28 \text { to } 45 \% \\
\text { [78] }\end{array}$ & - & \\
\hline $\begin{array}{l}\text { Metal waste (during mechanical process) (col- } \\
\text { lected for recycling) }\end{array}$ & $\mathrm{kg}$ & 24.76 & & 28.28 & \\
\hline $\begin{array}{l}\text { Impurities in scraps (paper, plastic, stone, rub- } \\
\text { ber) }\end{array}$ & $\mathrm{kg}$ & 50.00 & Estimated $5 \mathrm{wt} \%$ of aluminum scraps [19] & - & \\
\hline Furnace lining (refractory waste) & $\mathrm{kg}$ & 3.40 & & 3.88 & \\
\hline Skimming or dross when cleaning of furnace & $\mathrm{kg}$ & - & & 77.67 & \\
\hline Filter dust & $\mathrm{kg}$ & - & & 9.43 & \\
\hline Total wastewater & $\mathrm{kg}$ & $14,461.13$ & & 2659.22 & \\
\hline Wastewater (from cooling) & $\mathrm{kg}$ & $12,378.69$ & & 282.78 & \\
\hline Wastewater (from surface treatment) & $\mathrm{kg}$ & 2082.44 & & 2376.44 & \\
\hline
\end{tabular}

The solid waste stream has been grouped into metal slag, refractory waste, filter dust and skimming or dross during cleaning of smelters. Data on water using for cooling are $0.15-0.3 \mathrm{~m}^{3}$ per $\mathrm{t}$ of aluminum ingots [21]. After making ingots, mechanical processes are taken place to produce basins as final products. For surface treatment process, some BEP, cleaner production options will be implemented, such as switching from fully manual to semi-manual operation, better process control. Thus, the potential chemical reduction is approximately $70 \mathrm{wt} \%$ for chromic acid and $5 \mathrm{wt} \%$ for sodium hydroxide [74].

Detailed input and output data for aluminum recycling are shown in Table 8 in putting side by side with the current technology.
Table 8 presents the differences side-by-side between both scenarios. In selected BAT, more yield is produced and with that, water consumption and generated waste are reduced. It is obvious that aluminum loss in waste stream is reduced. New compared technology requires different types of energy so it is provided in energy unit (MJ) but it shows that significant reduction in energy consumption (roundly 3 times). To reduce the gap between two scenarios, new technology smelter suitable for old scrap types (e.g., reverberatory furnaces) might be necessary. Other solutions can be applied such as scrap sorting, better coal quality to reduce generated waste, better process control to improve energy efficiency (e.g., scrap cutting, better insulation, material charging process) and to improve surface treatment steps: water and chemical saving (e.g., applied reverse-order 
washing principle in which water is supplied only at the cleanest tank (the last one) and run over the previous tank, dripping time increase for products after taking them out from surface treatment tanks), water cooling tower for water recycling, air emission collection and treatment system and solid waste management program.

\section{Copper recycling}

Current technology Copper is recycled at traditional craft villages in Vietnam, such as Ngu Xa (Hanoi), Dai Bai (Bac Ninh province), Long Thuong (Hung Yen province), Phuoc Kieu (Quang Nam province) from copper scraps (mostly copper wires and other copper-contained parts: gears, locks, water faucets, disposed copper products, etc.) [13]. Each year, $1000 \mathrm{t}$ of copper products are made from recycled copper. For example, one craft village, Dai Bai village, has produced 300-400 t products annually [53]. Before 2009, when PCBs were used directly in copper smelters, Quang et al. [79] estimated that approximately 30-50 wt $\%$ of copper scraps came from e-waste sources. Currently, there is no estimation on that amount, but it is insignificant [5] as PCBs are no longer used straightly in the smelters as concerning about product quality and air pollutants (such as metal fume, organic compounds) during melting process.

The main products are decoration products (copper lotus flowers and leaves, statues, flower vases), products for worshiping purposes (incensories, candle stands), instrument (bells, gongs, drums). The products are made by smelting copper scraps in smelters, then casting in prepared molds. At copper casting craft villages, products are various in colors, shapes and sound. Different properties are resulted from different mixtures of copper with other metals $(\mathrm{Pb}, \mathrm{Zn}$,
$\mathrm{Pd}, \mathrm{Ni}$ ) and final mechanical processes (polishing, inlaying with other metals). For example, half-length statues have the mixture of $92 \mathrm{wt} \%$ of copper, $5 \mathrm{wt} \%$ of tin and $3 \mathrm{wt} \%$ of lead while outdoor statues can have a mixture from copper, tin, lead, zinc and nickel at the proportion of 85, 9, 3, 2 and $1 \mathrm{wt} \%$, respectively (interview data). Each smelter has different know-hows on metal combinations and processes that are usually transferred from one to another generation to make dissimilar types of products of their own and of with other smelters. Many smelters operate in workshops with no air treatment facility or sometimes in open space.

With the selected final products, half-length statues, the producing process includes 2 different steps (Fig. 7). The first step is mold preparation in which clay is mixed with water and after a day, the mixture is used for mold making. Molds can have 2 parts: outer and inner part and can have a cover layer with rice husk, paper, coal powder or biochar. Mold must be dried and heated before pouring liquid copper to prevent breaking or cracking. The second step is copper melting in furnace with some additional metals. After copper is melted, it is pouring into heated prepared molds. After cooling, molds are destroyed to collect casted products and clay from molds is recycled. Casted products are processed at the final mechanical step to form final look. Brief process is shown in Fig. 7.

The common smelters are traditional furnace using coal or fuel oil or combination of fuels (e.g., coal and wood). Generally, consumption data on producing $1 \mathrm{t}$ of final products consist of 1.05-1.18 t copper scraps [13, 19, 79], $1.0-1.2 \mathrm{t}$ coal and $1.5-1.8 \mathrm{t}$ wood $[13,79]$ or $2.52 \mathrm{t}$ coal [80], 5-6 t clay for molds, and approximately $3 \mathrm{~m}^{3}$ of water during mold making process (interview data). Energy is needed for 2 steps: (1) mold heating and (2) smelting and
Fig. 7 Flowchart of copper recycling at traditional craft village

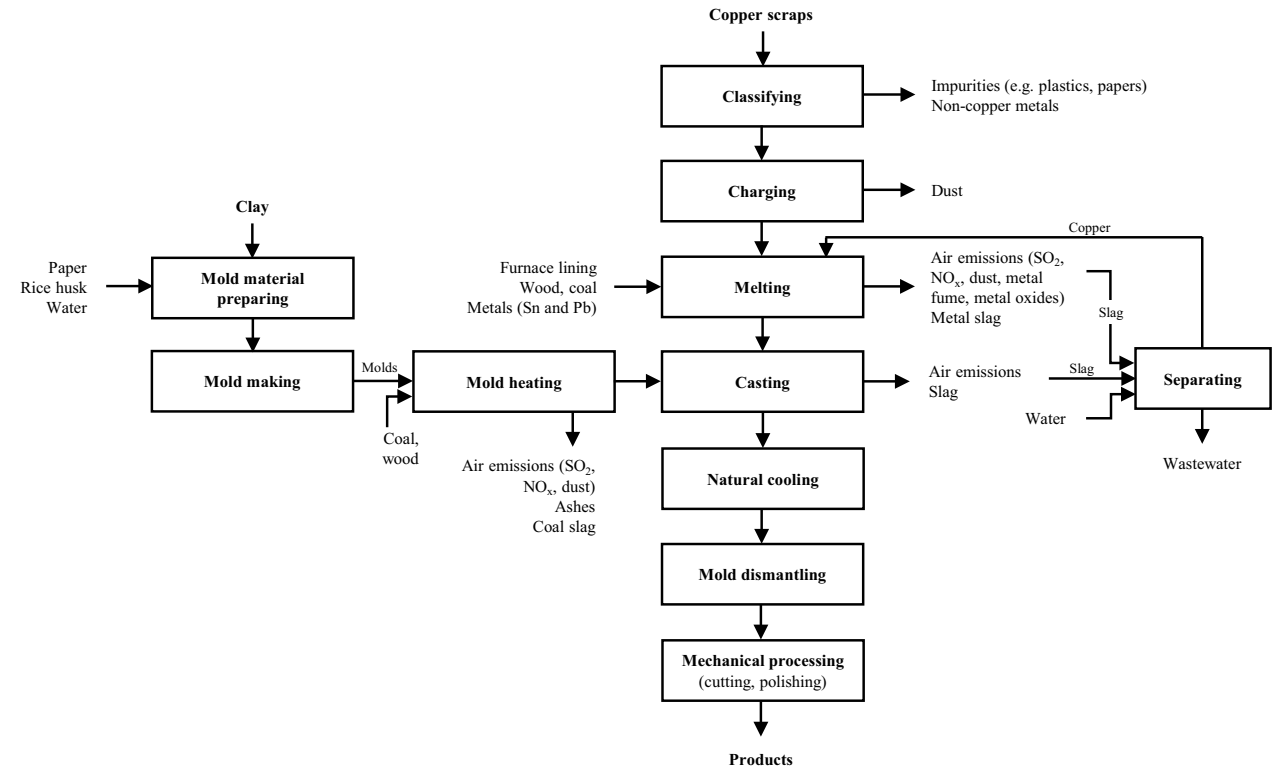


holding. Depending on the products, molds can be heated 2 times with different temperatures: 500 and $700{ }^{\circ} \mathrm{C}$, or until $1000-1200^{\circ} \mathrm{C}$. By calculating theoretically needed heat for clay-mold heating and copper smelting, it is estimated that about $80 \%$ of total energy has been used for mold heating. The rest is for smelting of copper.

Copper recycling process leads to several serious problems from waste streams. Air emission is the most critical issue as dust is generated in most all steps of recycling process. During scrap charging into the smelters, dust containing metals, soils are released into environment. Especially, during melting process, dust with fume metals and metal oxides, organic compounds from partly burned impurities, $\mathrm{CO}_{2}, \mathrm{CO}, \mathrm{NO}_{2}, \mathrm{SO}_{2}$ from burning of wood and coal is formed and emitted. Casting step with burning of materials from mold cover layer generates dust, $\mathrm{CO}_{2}, \mathrm{CO}$, etc. Dust is also caused from mold dismantling and from mechanical process. Moreover, during mold heating, the combustion of wood and coal is the source for air emission (dust, volatile ash, $\mathrm{CO}_{2}, \mathrm{CO}, \mathrm{NO}_{2}, \mathrm{SO}_{2}$, etc.).

Copper recycling is considered a "dry process" but the metal slag cleaning/separating step (Fig. 7) to recover partly metals results in pollution (metals, sediment) to water bodies (ponds, drainage channels) where metal slag is washed out. This practice is similar to the case of aluminum recovery from aluminum slag at aluminum casting craft villages.

Another waste stream is solid waste with impurities from sorting of scraps (about $1 \mathrm{wt} \%$ of scraps), coal slags (15-20 wt $\%$ of consumed coal [57, 75-77]), metal slags (dross) (10-15 wt\% of scraps [13] or $2-5 \mathrm{wt} \%$ of final products [19] and it depends on the quality of copper scraps) that can be recycled after washing with water, metal particles from mechanical processes $(0.5 \mathrm{wt} \%$ of final products [19]) and mold materials (clay). 90-92 wt\% of used clay can be recycled. In case of preparation or maintenance of smelters, refractory waste is appeared.

To calculate, we assume that the finished products are half-length statues with the final mixture of copper, tin and lead with the rates which have been provided above. With this combination, it forms bronze, a type of copper alloys [20]. The energy used for mold heating, copper smelting and casting is generated from coal and wood, in which the energy for smelting and holding is presumed from combustion of coal while wood is used for mold heating purpose. The data on inputs and outputs of copper recycling are shown in Table 9.

Selected BAT There are several technologies for secondary copper, such as blast, Mini Smelter, reverberatory or rotary furnace. The most appropriate technology for small size production/recycling is IF as this type of furnace is commonly used to produce copper alloys [21] due to high melting temperature and a wide range of melting capac- ity. Recyclers at craft villages can possibly upgrade to this technology. With selected BAT, some data are available. For example, residues from remelting processes consist of dross (or metal slag) (8-15 kg per $\mathrm{t}$ of copper product), flue dust (4-7 $\mathrm{kg}$ per $\mathrm{t}$ of copper product) and refractory lining ( $2 \mathrm{~kg}$ per $\mathrm{t}$ of copper product) [21]. The operating data for crucible induction furnace for the production of copper alloys [21] are used to compare with the current scenario with melting capacity which is $2.4-25 \mathrm{t}$ per $\mathrm{h}$; energy consumption is from 900 to $1600 \mathrm{MJ}$ per $\mathrm{t}$ of copper ingots. Furthermore, the data for metals given in Ecoinvent [22] are used in which $1 \mathrm{wt} \%$ of metals are lost during melting and $0.1 \mathrm{wt} \%$ of $\mathrm{Sn}$ and $\mathrm{Pb}$ input are lost in metal fume. This assumption is also applied to the current situation case. The difference between current process and selected BAT is that the selected BAT focuses on the melting and holding steps. To match both scenarios, energy consumption for the case of applied BAT is added with energy generated from coal and wood combustion (same amount of wood for current technology) for mold heating with presupposition of 7\% energy reduction (as evaluated by energy efficiency experts from VNCPC) by applying some cleaner production options such as installed better isolation layer for heating chamber, better process control. Clay used for mold making is remained the same.

Table 9 presents the differentiation between 2 technologies. It is visible that the energy consumption for current situation is higher than that of selected BAT, especially for the melting and holding steps. Selected BAT shows the significant reduction of solid waste stream as well. Due to the energy demand for molding preparation, energy consumption in the case of selected BAT is still high compared to the current situation. It shows the special case for copper recycling in Vietnam: making products instead of producing copper ingots. The proposed improvement potential options might be applied including new technology smelter (e.g., IF), scrap sorting, better process control to improve energy efficiency (e.g., scrap cutting, better insulation, material charging process), air emission collection (e.g., suction hood above smelter) and treatment system, water cooling tower for water recycling and solid waste management program.

\section{Results for desktop $\mathrm{PC}$ recycling}

\section{Summarization of critical flows}

From the analytic for each recycling process which includes process and data, the critical flows and some improvement potentials are summarized in Table 10 . Determining critical flows are based on some aspects, such as their quantity, potential to be collected by formal waste 
Table 9 The input and output data from recycling of $1000 \mathrm{~kg}$ copper scraps between current technology and selected BAT

\begin{tabular}{|c|c|c|c|c|c|}
\hline & \multirow[t]{2}{*}{ Unit } & \multicolumn{2}{|c|}{ Current technology } & \multicolumn{2}{|c|}{ Selected BAT } \\
\hline & & Quantity & Note & Quantity & Note \\
\hline \multicolumn{6}{|l|}{ Input } \\
\hline Copper scraps & $\mathrm{kg}$ & 1000.00 & & 1000.00 & \\
\hline $\mathrm{Sn}$ & $\mathrm{kg}$ & 52.50 & \multirow{2}{*}{$\begin{array}{l}\text { Calculated based on the assumption } \\
\text { of } 1 \mathrm{wt} \% \text { metals lost during melt- } \\
\text { ing and } 0.1 \mathrm{wt} \% \text { metals lost in air } \\
\text { emission. }\end{array}$} & 54.35 & \multirow{2}{*}{$\begin{array}{l}\text { Calculated based on the assump- } \\
\text { tion of } 1 \mathrm{wt} \% \text { metals lost during } \\
\text { melting and } 0.1 \mathrm{wt} \% \text { metals lost in } \\
\text { air emission }\end{array}$} \\
\hline $\mathrm{Pb}$ & $\mathrm{kg}$ & 31.50 & & 32.61 & \\
\hline $\begin{array}{l}\text { Energy for mold heating, smelting } \\
\text { and holding }\end{array}$ & MJ & $46,032.72$ & & $37,139.14$ & \\
\hline Energy for smelting and holding & MJ & 9223.84 & & 1704.95 & Manual casting \\
\hline Clay (recycled) & $\mathrm{kg}$ & 5095.76 & & 5274.68 & \\
\hline Clay (new) & $\mathrm{kg}$ & 566.20 & & 586.08 & \\
\hline Water & $\mathrm{kg}$ & 3088.34 & & 3196.77 & \\
\hline \multicolumn{6}{|l|}{ Output } \\
\hline Final Products & $\mathrm{kg}$ & 1029.45 & $\begin{array}{l}\text { Half-length statues (as a bronze } \\
\text { type) with Copper, } \mathrm{Sn} \text { and } \mathrm{Pb} \text { at } \\
\text { the proportion of } 92,5 \text { and } 3 \% \text {, } \\
\text { respectively }\end{array}$ & 1065.59 & $\begin{array}{l}\text { Half-length statues (as a bronze } \\
\text { type) with Copper, } \mathrm{Sn} \text { and } \mathrm{Pb} \text { at } \\
\text { the proportion of } 92,5 \text { and } 3 \% \text {, } \\
\text { respectively }\end{array}$ \\
\hline $\mathrm{Pb}, \mathrm{Sn}$ in air emission & $\mathrm{kg}$ & 0.08 & & 0.09 & \\
\hline Equivalent $\mathrm{CO}_{2}$ emission & $\mathrm{kg}$ & 2959.31 & $\begin{array}{l}\text { Calculated from data provided in } \\
\text { Table } 3 \text {. The } \mathrm{CO}_{2} \text { emission from } \\
\text { wood burning is not counted as a } \\
\text { biomass source }\end{array}$ & 2030.53 & $\begin{array}{l}\text { Calculated from data provided in } \\
\text { Table } 3 \text {. The } \mathrm{CO}_{2} \text { emission from } \\
\text { wood burning is not counted as a } \\
\text { biomass source }\end{array}$ \\
\hline Total solid waste & $\mathrm{kg}$ & 882.08 & & 740.79 & \\
\hline Coal slag and ashes & $\mathrm{kg}$ & 205.89 & & 125.89 & \\
\hline Dust from filter to recycling & $\mathrm{kg}$ & - & & 10.71 & $\begin{array}{l}\text { With air treatment facility (filter } \\
\text { bags) }\end{array}$ \\
\hline Metal slags & $\mathrm{kg}$ & 100.00 & & 15.98 & \\
\hline Refractory lining waste & $\mathrm{kg}$ & - & & 2.13 & \\
\hline $\begin{array}{l}\text { Solid waste (impurities such as } \\
\text { paper, plastic, rock) }\end{array}$ & $\mathrm{kg}$ & 10.00 & & - & \\
\hline $\begin{array}{l}\text { Solid waste (clay as mold materi- } \\
\text { als) }\end{array}$ & $\mathrm{kg}$ & 566.20 & & 586.08 & \\
\hline Clay (to be recycled) & $\mathrm{kg}$ & 5095.76 & & 5274.68 & \\
\hline $\begin{array}{l}\text { Copper loss in mechanical pro- } \\
\text { cesses (cutting, polishing) to } \\
\text { recycling }\end{array}$ & $\mathrm{kg}$ & 5.15 & $\begin{array}{l}\text { Approximately } 0.5 \mathrm{wt} \% \text { output metal } \\
\text { [19] }\end{array}$ & 5.33 & $\begin{array}{l}\text { Approximately } 0.5 \mathrm{wt} \% \text { output } \\
\text { metal [19] }\end{array}$ \\
\hline
\end{tabular}

collection, potential to be collected by informal waste collectors for recycling, recycling practices, availability of waste pre-treatment/treatment facility (e.g., sedimentation tanks, air sucking system). Some practical improvement potentials have been suggested based on cleaner production assessment reports from metal and plastic recycling sectors (see "Materials and methods"). More improvement potentials can be retrieved from BAT reference documents.

As seen from Table 10, the most serious issue is air emission from most of recycling processes but there are no available data for pollutant concentration. Gaseous emission consists of not only $\mathrm{CO}_{2}$ and other gases $\left(\mathrm{NO}_{x}, \mathrm{SO}_{x}\right.$, etc.) from fuel combustion but also metal and metal oxide fumes and organic compounds from contaminated scraps or from formation of monomers under pyrolysis of plastic. Wastewater with heavy metals and chemicals from gold recovery and surface treatment of aluminum products requires special treatment. Moreover, metal recovering activities from metal slag in case of aluminum and copper recycling by washing metal slag in water lead to critical problem of water pollution to water received bodies such as ponds, lakes, water channels. Solid waste stream is an issue relating to copper recovery from $\mathrm{PCBs}$ as it contains flame retardants while metal slags from metal recycling might contain heavy metals and other compounds. 


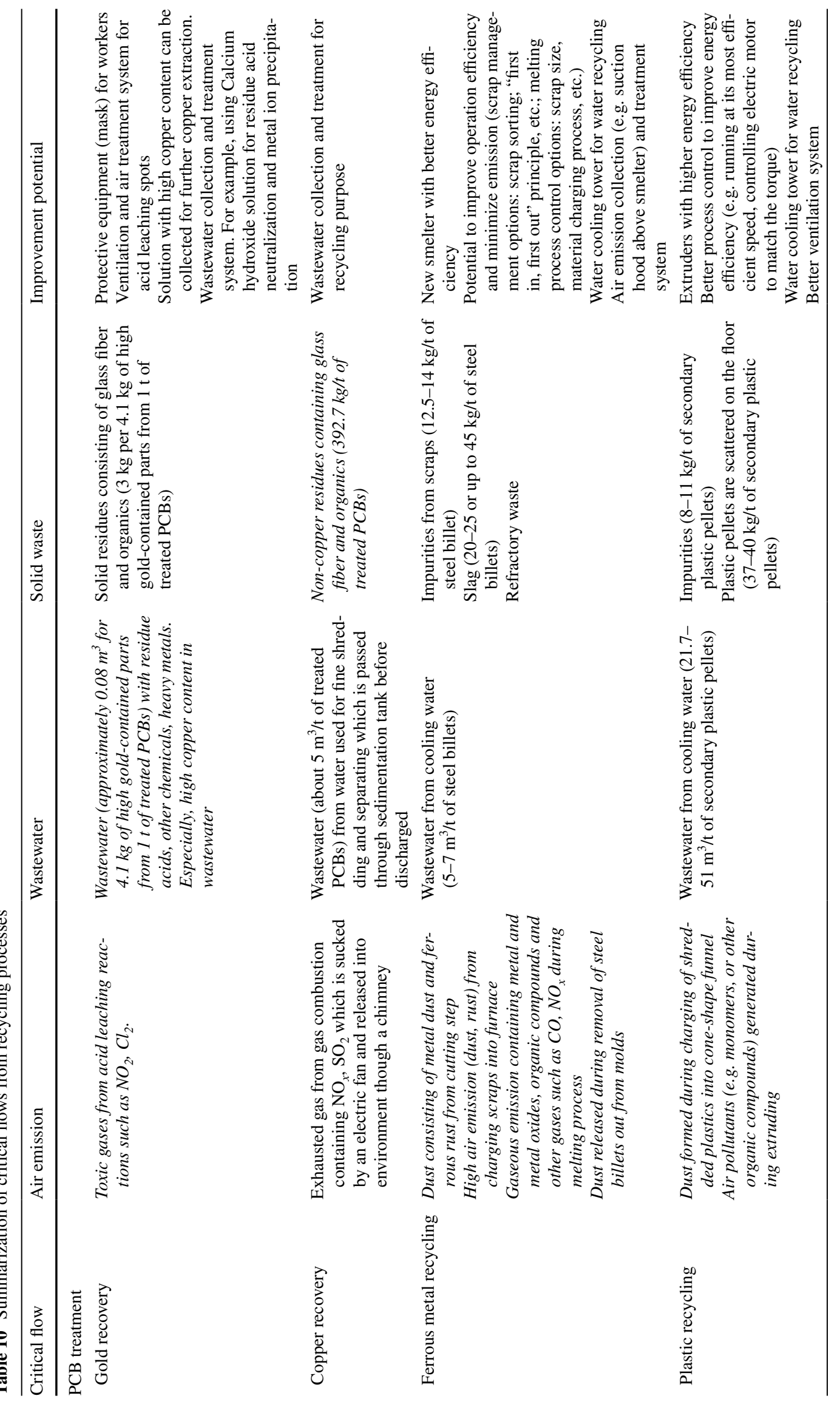




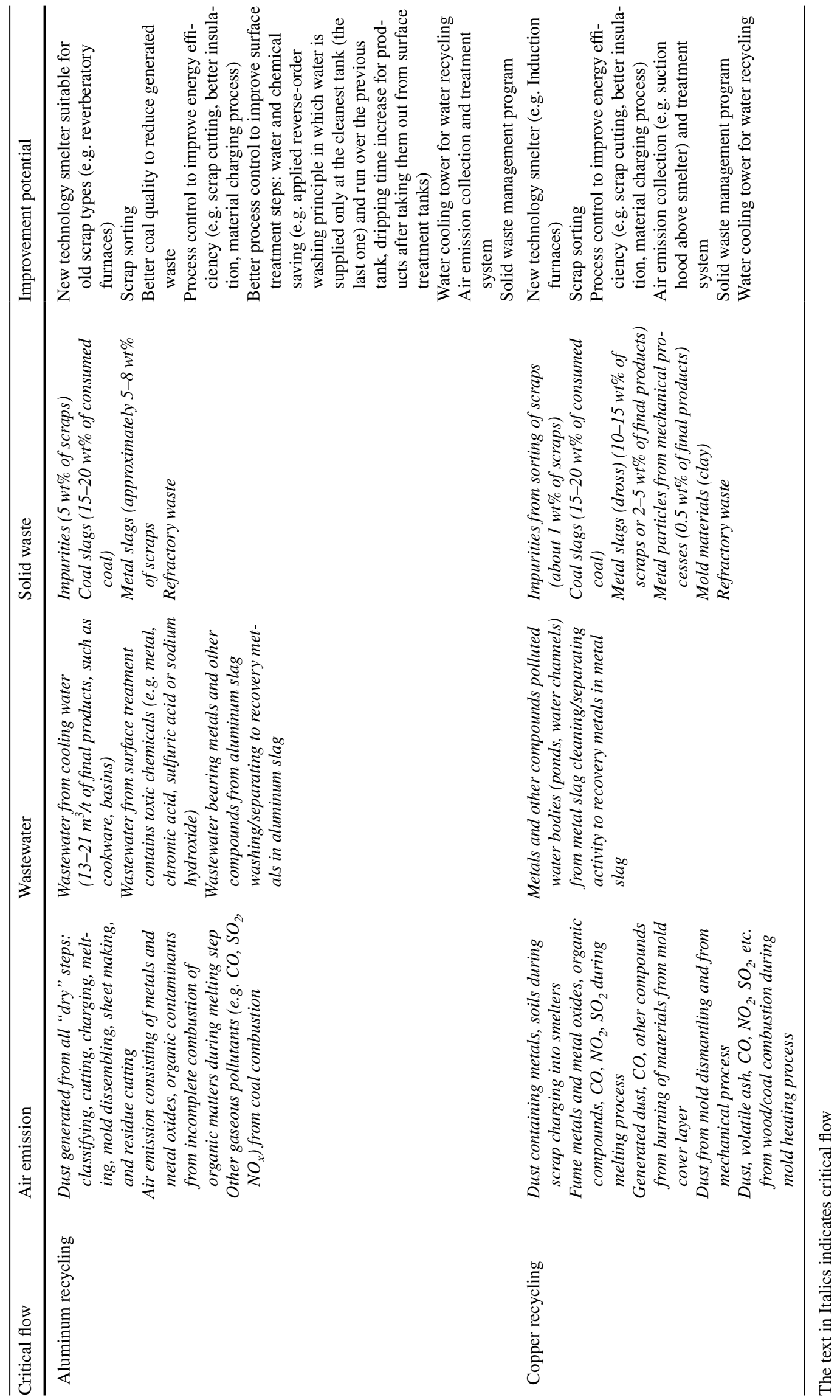



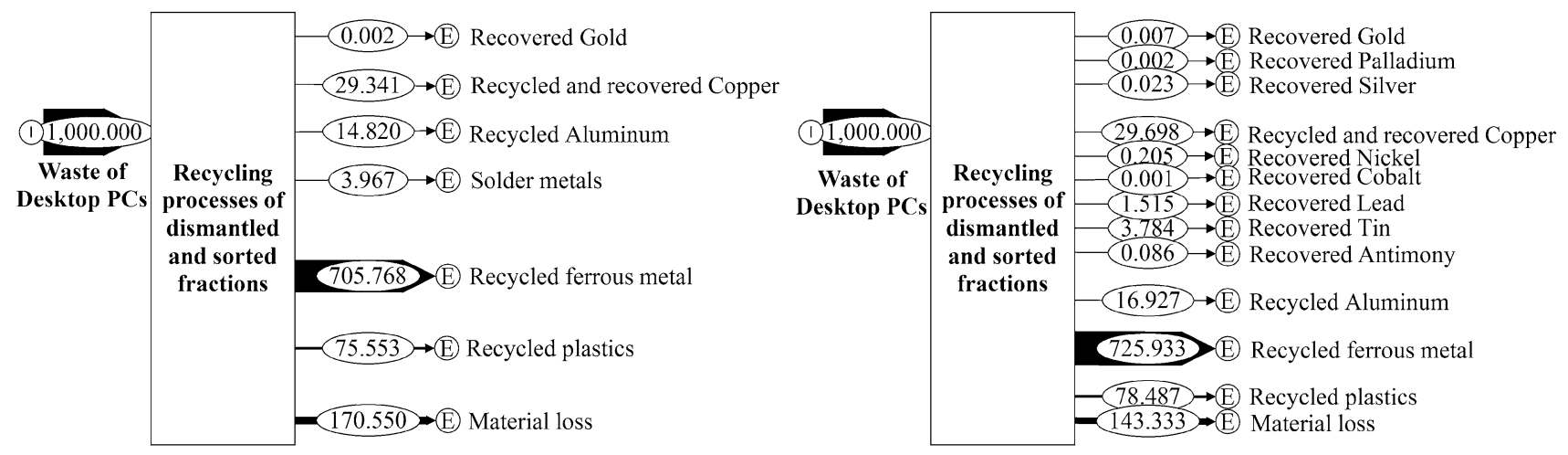

Fig. 8 Recovered and recycled materials ( $\mathrm{kg}$ ) from recycling processes of waste PC under current technologies (left-hand side) and selected BATs (right-hand side)

Table 11 Comparison between current technologies and selected BAT under energy consumption and waste streams

\begin{tabular}{lccc}
\hline & Unit & $\begin{array}{l}\text { Current technologies } \\
\text { Quantity }\end{array}$ & $\begin{array}{l}\text { Selected BAT } \\
\text { Quantity }\end{array}$ \\
\hline $\begin{array}{l}\text { Energy consumption } \\
\text { Electricity consump- } \\
\text { tion }\end{array}$ & $\mathrm{kWh}$ & 747.731 & 439.387 \\
$\begin{array}{l}\text { Fuels (coal, LPG, } \\
\quad \text { wood) }\end{array}$ & $\mathrm{MJ}$ & 672.554 & 361.110 \\
$\begin{array}{l}\text { Waste stream } \\
\text { Wastewater (total) }\end{array}$ & $\mathrm{kg}$ & 5743.700 & \\
$\begin{array}{l}\text { Solid waste (total) } \\
\text { Equivalent } \mathrm{CO}_{2} \text { emis- }\end{array}$ & $\mathrm{kg}$ & 127.581 & 47.754 \\
$\quad \mathrm{~kg}$ & 401.689 & 66.409 \\
\hline sions & & & 239.988 \\
\hline
\end{tabular}

\section{Comparison between two scenarios}

Using Tables 1, 2, 3, 4, 5, 6, 7, 8 and 9 to apply for $1 \mathrm{t}$ of waste from desktop PC, the main outputs from recycling processes in terms of recovered and recycled of metals and plastics are presented in Fig. 8. As seen from Fig. 8, more precious, base and rare metals are recovered in the case of BAT compared to the current technologies. It is noted that the material loss consists of many metals containing in electronic components from PBCs (capacitors, transistors) that are exported to China for further treatment. The material loss is not much different in weight as the highest fractions are ferrous metals and plastics that are recycled within the territory of Vietnam.

The selected BAT include the energy recovery from burning of non-metal fraction of PCBs and the appearance of by-products from PCB treatment under Umicore's technologies for construction materials (both non-metal fraction and metals in by-products appear in the material loss). The loss of materials is in the form of solid waste, wastewater (metal loss from gold recovery process in the first scenario under acid leaching) and air emissions (dust, metal fume, organic compounds).

As shown in Table 11, the current technologies have higher energy consumption than that of selected BATs. Thus, more equivalent $\mathrm{CO}_{2}$ emission is emitted. Solid waste in the first scenario contains the organic fraction from PCB treatment for copper recovery and it is possible to contain other metals. It is important to emphasize that air emission is just quantifiable or calculable proportion while more air pollution from melting (and casting) of ferrous metal, copper, aluminum and plastic are not able to calculate because of missing information.

\section{Conclusion}

The study focuses on the process and data collection phase for desktop personal computer recycling processes under 2 proposed scenarios: (1) current technologies in which outputs from dismantling processes are passed through the gold and copper recovering, and metal and plastic recycling at craft villages in Vietnam, and (2) appropriate BAT (or Best Available Technologies). Only for the case of Printed Circuit Board treatment, the selected BAT are technologies that cannot be implemented locally. The rest (metal and plastic recycling) of the selected BAT are considered suitable to be implemented at craft villages in terms of production capacity, fuel sources.

The informal end-processing/recycling of desktop personal computer waste includes Printed Circuit Board treatment, metal recycling (ferrous metal, aluminum and copper) and plastic recycling. Each recycling process has been described that consists of inputs and outputs and the data on the quantity of inputs (scrap, energy, water and other materials) and outputs (final products and waste streams). 
Especially, the most critical issues have been analyzed. Unfortunately, data on air emission are missing for all recycling processes as lacking of studies on generated pollutants from informal recycling practices. Thus, those missing data should be measured.

In comparison between 2 scenarios, it is visible that selected Best Available Techniques are more advanced compared to the current technologies in both recovered and recycled amount of metals and plastic, water and energy consumption, and waste generation. Electricity and fuel consumption for the current technologies are higher than those of selected BAT about 1.7 and 1.9 times, respectively. Wastewater containing chemical and liquid metal salt from gold recovery using acid leaching needs to be treated properly or collected for further copper (and other metal) extraction. A large volume of water using for cooling purpose has high potential to be recycled. Without recycling, the quantity of water and wastewater for current technologies is 120 times higher compared to the selected BAT. The amount of solid waste from the first scenario is generated at 1.9 times higher than that from the scenario.

This study is an initial and necessary step for building up Life Cycle Inventory for informal e-waste recycling in Vietnam. With further studies focusing on air emission from end-processing of e-waste, Life Cycle Assessment shall be calculated and the comparison between current situation and BAT/BEP in terms of life cycle indicators shall be drawn. Those figures could support decision makers in supporting the informal sectors in several ways, for example, supporting the technology upgrading individually or consolidating the current trend which is to gather processers into centralized workshops with treatment facilities, etc. Obviously, this study is limited in air emission data. In the first scenario, environmental monitoring data are available in some studies but impossible to calculate the air emission as the melting practices are without air treatment facilities. In the second scenario, the air pollutant concentration after treated at appropriate air treatment facilities but the sucked air volume is not available for specific recycling process (such as scrap quality, production capacity, air treatment technologies). More importantly, input analysis (organic matters, metal content) is needed for better calculation but there are no data available. From these limitations, it is suggested that further studies are needed to fulfill the requirement for technology assessment and for an e-waste recycling inventory in informal sector in Vietnam.

Acknowledgements Open access funding provided by University of Natural Resources and Life Sciences Vienna (BOKU). This research has been supported by ERASMUS MUNDUS Techno II project-a Euro-Asia partnership to promote Engineering Technology Education and Research Exchanges, the Institute of Waste Management, University of Natural Resources and Life Sciences, Vienna and Vietnam Cleaner Production Centre.
Open Access This article is distributed under the terms of the Creative Commons Attribution 4.0 International License (http://creativecommons.org/licenses/by/4.0/), which permits unrestricted use, distribution, and reproduction in any medium, provided you give appropriate credit to the original author(s) and the source, provide a link to the Creative Commons license, and indicate if changes were made.

\section{References}

1. Baldé CP, Wang F, Kuehr R, Huisman J (2014) The global e-waste monitor-2014. United Nations University, IAS, SCYCLE, Bonn

2. Norgate TE, Rankin WJ (2002) The role of metals in sustainable development. In: Green processing 2002: international conference on the sustainable processing of minerals, Cairns, QLD. AusIMM, pp 49-55

3. Cui J, Forssberg E (2003) Mechanical recycling of waste electric and electronic equipment: a review. 99(3):243-263. https://doi. org/10.1016/S0304-3894(03)00061-X

4. GSO (2016) Statistical yearbook of Vietnam 2015. Statistical Publishing House, General Statistics Office of Vietnam. https:// www.gso.gov.vn/Modules/Doc_Download.aspx?DocID=19981. Accessed 10 Jan 2017

5. Tran CD, Salhofer SP (2016) Analysis of recycling structures for e-waste in Vietnam. J Mater Cycles Waste Manag. https://doi. org/10.1007/s10163-016-0549-1

6. URENCO (2007) The development of e-waste inventory in Vietnam. Urban Environment One Member State-Owner Limited Company Vietnam, Hanoi. http://archive.basel.int/techmatters/e wastes/E-waste\%20Inventory\%20in\%20Vietnam.pdf. Accessed 7 July 2016

7. Feige EL (1990) Defining and estimating underground and informal economies: the new institutional economics approach. World Dev 18(7):989-1002. https://doi.org/doi. org/10.1016/0305-750X(90)90081-8

8. Scheinberg A, Simpson M, Gupt Y, Anschütz J, Haenen I, Tasheva E, Hecke J, Soos R, Chaturvedi B, Garcia-Cortes S, Gunsilius E (2010) Economic aspects of the informal sector in solid waste management, vol 1. https://www.giz.de/expertise/downloads/ gtz2010-en-Economic-Aspects-WASTE.pdf. Accessed 8 June 2017

9. OSPAR Commission (2007) OSPAR Convention: appendix 1. Criteria for the definition of practices and techniques mentioned in paragraph 3(b)(i) of Article 2 of the Convention. http://www. ospar.org/site/assets/files/1290/ospar_convention_e_updated_ text_in_2007_no_revs.pdf. Accessed 27 Oct 2016

10. VNCPC and VEA (2011) Technical booklet for "applying best available techniques (BAT) and best environment practices (BEP) to eliminate persistent organic pollutants in steel-making process-electric arc furnace (EAF). Vietnam Cleaner Production Centre and Pollution Control Agency, Vietnam Environment Administration

11. Centre for Science and Environment (2012) Best available techniques for Indian Iron and Steel Sector. http://www.cseindia.org/ userfiles/GRP\%20BAT\%20guidelines\%20steel\%20sector\%20pdf. pdf. Accessed 27 Sept 2016

12. Gmünder S (2007) Recycling - from waste to resource-assessment of optimal manual dismantling depth of a desktop PC in China based on eco-efficiency calculations. Diploma Thesis. Delft University of Technology (TU Delft)

13. NIES and INEST (2011) Research on classification of e-waste processing technology in Vietnam. The National Institute for Environmental Studies of Japan and the Institute for Environmental Science and Technology, Vietnam 
14. Hai HT, Hung HV, Quang ND (2015) An overview of electronic waste recycling in Vietnam. J Mater Cycles Waste Manag. https:// doi.org/10.1007/s10163-015-0448-x

15. Yoshida A, Terazono A, Ballesteros FC Jr, Nguyen D-Q, Sukandar S, Kojima M, Sakata S (2016) E-waste recycling processes in Indonesia, the Philippines, and Vietnam: A case study of cathode ray tube TVs and monitors. Resour Conserv Recycl 106:48-58. https://doi.org/10.1016/j.resconrec.2015.10.020

16. Pham-Ngoc D, Nguyen-Ngoc S, Dang-Kim C, Tang-The C, Pham-Quy N, Nguyen-Hung T, Nguyen-Hoang A (2016) National State of Environment in the period of 2011-2015. Ministry of Natural Resources and Environment, Vietnam. http://tcmt.monre.gov.vn/pages/article.aspx?item $=\mathrm{B} \% \mathrm{C} 3 \% \mathrm{~A} 1 \mathrm{o}-$ c\%C3\%A1o-hi\%E1\%BB\%87n-tr\%E1\%BA\%A1ng-m\%C3\%B4itr\%C6\%B0\%E1\%BB\%9Dng-qu\%E1\%BB\%91c-gia-giai-\%C4\%9 1o\%E1\%BA\%A1n-2011-2015-42030. Accessed 22 Dec 2016

17. MONRE (2008) National State of Environment 2008-Vietnam Craft Village Environment. Ministry of Natural Resources and Environment, Vietnam. http://cem.gov.vn/Portals/0/DULIEU/ bao\%20cao/SoE_2008_Eng.pdf. Assessed 8 July 2016

18. MONRE (2012) Vietnam National Environment Report 2011. Ministry of Natural Resources and Environment, Vietnam. http:// quantracmoitruong.gov.vn/Portals/0/Bao\%20cao/SOE\%202011/ Baocaomoitruongquocgia2011.pdf. Accessed 11 May 2016

19. Dang K-C (2005) Scientific and realistic basic research for building up policies and solutions for environmental issues in craft villages of Vietnam. Hanoi University of Technology, Institute of Environmental Science and Technology, Hanoi

20. European Commission (2005) Integrated pollution prevention and control. Reference document on best available techniques in the smitheries and foundries industry. http://eippcb.jrc.ec.europa.eu/ reference/BREF/sf_bref_0505.pdf. Accessed 10 Oct 2016

21. European Commission (2014) Best available techniques (BAT) reference document for the non-ferrous metals industries-final draft. http://eippcb.jrc.ec.europa.eu/reference/BREF/NFM_Final_ Draft_10_2014.pdf. Accessed 10 Oct 2016

22. Classen M, Althaus H-J, Blaser S, Tuchschmid M, Jungbluth N, Emmenegger MF (2009) Life cycle inventories of metals. Final report ecoinvent v2.1, No.10. Empa Dübendorf, Swiss Centre for Life Cycle Inventories, Dübendorf, $\mathrm{CH}$

23. Hischier R (2007) Life cycle inventories of packaging and graphical paper. Ecoinvent-Report No. 11, Part II. Plastics, Swiss Centre for Life Cycle Inventories. Dübendorf

24. Hischier R, Classen M, Lehmann M, Scharnhorst W (2007) Life cycle inventories of electric and electronic equipment: production, use and disposal. Ecoinvent report no. 18. Part V. Disposal of electric and electronic equipment (e-Waste). Empa/Technology and Society Lab, Swiss Centre for Life Cycle Inventories, Dübendorf

25. Beigl P, Salhofer SP (2016) Untersuchung der Zusammensetzung von Elektrokleingeräten und Entwicklung einer Demontagedatenbank. In: Recy \& DepoTech 2016, Leoben, Austria. NovAbfallverwertungstechnik und Abfallwirtschaft, Montanuniversität Leoben, pp 397-402 (German language)

26. General Directorate of Energy (2015) Vietnam energy policy. Ministry of Industry and Trade. https://eneken.ieej.or.jp/ data/6238.pdf. Accessed 19 Oct 2016

27. STAMEQ (2015) TCVN 8910:2015. National Standards for commercial coal-specifications. Vietnam Directorate for Standards, Metrology and Quality. http://thanmiennam.com/UserFiles/file/ TCVN\%208910.pdf. Accessed 5 Oct 2016

28. US EPA (2008) Section 1.5. Liquified petroleum gas combustion. Chapter 1: external combustion sources, AP 42, 5th edn, vol I. https://www3.epa.gov/ttn/chief/ap42/ch01/bgdocs/b01s05.pdf. Accessed 17 Oct 2016

29. Hahn E (2016) LPG conversion values: gas kg, litres, MJ, kWh and $\mathrm{m}^{3}$. ELGas. http://www.elgas.com.au/ blog/389-lpg-conversions-kg-litres-mj-kwh-and-m3. Accessed 18 Oct 2016

30. US EPA (2003) Section 1.6. Wood Residue combustion in boilers. Chapter 1: external combustion sources, AP 42, 5th edn, vol I. https://www3.epa.gov/ttn/chief/ap42/ch01/final/c01s06.pdf. Accessed 17 Oct 2016

31. Brander M, Sood A, Wylie C, Haughton A, Lovell J (2011) Technical paper, electricity-specific emission factors for grid electricity. https://ecometrica.com/assets/Electricity-specific-emissionfactors-for-grid-electricity.pdf. Accessed 11 Oct 2016

32. Le H-L, Yamasue E, Okumura H, Ishihara KN (2013) MEMRECS - a sustainable view for metal recycling from waste printed circuit boards. J Environ Prot 04(08):803. https://doi.org/10.4236/ jep.2013.48094

33. Keller M (2006) Assessment of gold recovery processes in Bangalore, India and evaluation of an alternative recycling path for printed wiring boards. Master thesis. Swiss Federal Institute of Technology (ETH), Materials Science and Technology Research Institute (Empa), Zurich \& St. Gallen/Switzerland

34. Rochat D, Hagelüken C, Keller M, Widmer R (2007) Optimal Recycling for Printed Wiring Boards (PWBs) in India. In: Paper presented at the R'07 recovery of materials and energy for resource efficiency, Davos, Switzerland

35. Williams E, Kahhat R, Bengtsson M, Hayashi S, Hotta Y, Totoki Y (2013) Linking informal and formal electronics recycling via an interface organization. Challenges 4(2):136-153. https://doi. org/10.3390/challe4020136

36. AMP Incorporated (2004) Technical report: golden rules: guidelines for the use of gold on connector contacts. http://www.te.com/ documentation/whitepapers/pdf/aurulrep.pdf. Accessed 6 Dec 2016

37. PCBsourcing (2016) Gold Finger Printed Circuit Board. http:// www.pcbsourcing.com/Business/gfp.html. Accessed 6 Dec 2016

38. sreetips (13 September 2015) How To recover gold from computer scrap with household chemicals. https://www.youtube.com/ watch?v=2sZUAprS5KI. Accessed 25 Jan 2017

39. Mike the Scrapper (03 June 2013) How to recover gold with A/P acid peroxide method for gold fingers and gold plated boards easily. https://www.youtube.com/watch? $\mathrm{v}=\mathrm{oCwgBkStY}$ _Y. Accessed 25 Jan 2017

40. arches100 (2015) Recovering gold from RAM memory (100 pieces). https://www.youtube.com/ watch?v=alqOCgoY8Gg. Accessed 25 Jan 2017

41. Mike the Scrapper (2014) Gold recovery (green fiber CPU pins). https://www.youtube.com/watch?v=-mB6xZLXOxw. Accessed 25 Jan 2017

42. Sheng PP, Etsell TH (2007) Recovery of gold from computer circuit board scrap using aqua regia. Waste Manag Res 25(4):380 383. https://doi.org/10.1177/0734242X07076946

43. Li J, Duan H, Yu K, Liu L, Wang S (2010) Characteristic of low-temperature pyrolysis of printed circuit boards subjected to various atmosphere. Resources, Conservation and Recycling 54(11):810-815. https://doi.org/10.1016/j.resconrec.2009.12.011

44. MBMM (2016) Turnkey PCB processing system. Mt. baker mining and metals. http://www.mbmmllc.com/product/pcb-processing-turn-key-system/. Accessed 5 Oct 2016

45. SSC, UNEP, UNIDO, UNITAR, UN (2012) Guidance on best available techniques and best environmental practices for the recycling and waste disposal of articles containing polybrominated diphenyl ethers (PBDEs) listed under the Stockholm Convention (Draft version). Secretariat of the Stockholm Convention (SSC), United Nations Environment Programme (UNEP), United Nations Industrial Development Organization (UNIDO), United Nations Institute for Training and Research (UNITAR), United Nations (UN). http://chm.pops.int/Portals/0/download.aspx?d=UNEPPOPS-NIP-GUID-BATBEPPBDE.En.pdf. Accessed 12 Oct 2016 
46. Isaksson Ö, Lehner T (2000) The rönnskär smelter project: production, expansion, and start-up. JOM 52(8):26-29. https://doi. org/10.1007/s11837-000-0169-y

47. Hagelüken C (2006) Recycling of electronic scrap at Umicore's integrated metals smelter and refinery. World Met ERZMETALL 59(3):152-161

48. Hagelüken C (2007) Metals recovery from e-scrap in a global environment technical capabilities, challenges and experience gained. In: Paper presented at the sixth session of open-ended working group (OEWG) of the basel convention, Geneva, Switzerland

49. Khaliq A, Rhamdhani M, Brooks G, Masood S (2014) Metal extraction processes for electronic waste and existing industrial routes: a review and Australian perspective. Resources 3(1):152179. https://doi.org/10.3390/resources3010152

50. Umicore (2017) Umicore precious metals refining. http://pmr. umicore.com/en/recyclables/electronic-scrap/process/. Accessed 6 Oct 2017

51. Umicore (2017) Umicore environmental statements. http://annualreport.umicore.com/media/1288/ar2016environmentalen.pdf. Accessed 10 Oct 2017

52. VSA (2015) Research on induction furnace (IF) in Vietnam. Vietnam Steel Association (VSA). Hanoi, Vietnam. Vietnamese language

53. Nguyen Thi-Quynh-Chi (2014) Evaluation of soil and water environment and proposed solutions to reduce pollution at Man Xa Aluminum casting village, Van Mon Commune, Yen Phong district, Bac Ninh province. Masterthesis. Vietnam National University of Agriculture. Vietnamese language

54. MoIT (2011) Cleaner Production guidebook in Metal processing. Cleaner Production Component of Vietnam Ministry of Industry and Trade (MoIT). Hanoi, Vietnam. Vietnamese language

55. VNCPC (2006) Cleaner production assessment report at Dai Thang Casting Co., Ltd. Vietnam Cleaner Production Centre. Unpublished work

56. VNCPC (2006) Cleaner production assessment report at Tien Dat Mechanism and Casting Co., Ltd. Vietnam Cleaner Production Centre. Unpublished work

57. VNCPC (2006) Cleaner production assessment report at Xuan Phong Co., Ltd. Vietnam Cleaner Production Centre. Unpublished work

58. VNCPC (2010) Detailed assessment report at Viet-Phap Steel Co., Ltd. for Green Credit Trust Fund. Vietnam Cleaner Production Center. Unpublished work

59. Thai N-T-K, Huong L-T-M (2011) Evaluation of solid waste management at recycling craft villages and suggestion of management solution. J Sci Technol Civ Eng 9(5):114-120

60. Pacific Environmental Services I, Park RT (2003) Background report: AP-42 Section 12.10: iron foundries. Report prepared for US Environment Protection Agency. https://www3.epa.gov/ ttnchie1/ap42/ch12/bgdocs/b12s10.pdf. Accessed 20 Dec 2016

61. World Steel Association (2016) World Steel Association-water management in the steel industry. https://www.worldsteel.org/ publications/position-papers/Water-management.html. Accessed 12 Oct 2016

62. Dimitrakakis E, Janz A, Bilitewski B, Gidarakos E (2009) Small WEEE: determining recyclables and hazardous substances in plastics. 161(2-3):913-919. https://doi.org/10.1016/j. jhazmat.2008.04.054

63. UNEP (2010) Technical review of the implications of recycling commercial pentabromodiphenyl ether and commercial octabromodiphenyl ether-draft. United Nations Environment Programme. http://chm.pops.int/Portals/0/download. aspx?d=UNEP-POPS-POPRC.6-2-Annex.English.pdf. Accessed 12 Oct 2016

64. PlasticsEurope (2016) Acrylonitrile-butadiene-styrene (ABS). http://www.plasticseurope.org/what-is-plastic/types-of-plastics-11148/engineering-plastics/abs.aspx. Accessed 27 Sept 2016

65. VNCPC (2011) Report on the implementation of promoting resource efficiency in small and medium sized enterprises at Nguyen Tan Production and Trading Private Enterprise. Unpublished work

66. VNCPC (2011) Full assessment report Dao Van Tung household enterprise-an application for the Green Credit Trust Fund. Unpublished work

67. Dinh An JSC. (2013) Project investment registration document for Green Credit Trust Fund: Dinh An JSC

68. DeMatteo R (2011) Chemical exposure and plastics production: issues for women's health. A review of literture. http://www. nnewh.org/images/upload/attach/2502NNEWH\%20Lit\%20 Review\%20-\%20Chem\%20Exp\%20and\%20Plastics\%20Production.pdf. Accessed 25 Dec 2016

69. VNCPC (2008) Cleaner production assessment report at My Hung Co., Ltd. Unpublished work

70. Hopewell J, Dvorak R, Kosior E (2009) Plastics recycling: challenges and opportunities. Philos Trans R Soc Lond B Biol Sci 364:2115-2126. https://doi.org/10.1098/rstb.2008.0311 (vol 1526)

71. Kent R (2009) What's your process energy fingerprint? Plastic Technology. http://www.ptonline.com/articles/whats-your-process-energy-fingerprint. Accessed 13 Oct 2016

72. BKG (2015) Underwater pelletizing systems. Nordson Corporation. http://www.extrusionauxiliary.com/sitebuildercontent/sitebuilderfiles/BKGpelletizers.pdf. Accessed 26 Dec 2016

73. VNCPC (2005) Cleaner production assessment report at Quang Dung private manufacturer. Unpublished work

74. VNCPC (2006) Summarization of the implementation of cleaner production assessment and hazardous waste management at Van Chang craft villages. Unpublished work

75. VNCPC (2005) Cleaner production assessment at Cong Minh Co., Ltd. Vietnam Cleaner Production Centre

76. VNCPC (2006) Cleaner production assessment report at Nam Ninh Mechanism-Casting Co., Ltd. Unpublished work

77. VNCPC (2009) Development of a resource efficiency improvement programme in SMEs report at Ha Nguyet Co., Ltd. Unpublished work

78. Ha P-T-T (2009) Summary report of the study on treatment technology of aluminum slag for alum recovery from secondary aluminum recycling. National Institute of Mining-Metallurgy Science and Technology (VIMLUKI)

79. Duc-Quang Nguyen YE, Okumura H., Ishihara KN (2006) Wastes of electronic and electric equipment (WEEE) recycling system in Vietnam: a case study on copper recycling. In: Proceedings of the second joint international conference on sustainable energy and environment (SEE 2006), vol 2, Bangkok

80. Le T-C-H (2008) Environmental assessment study and pollution controlling methods at the Phuoc Kieu Copper casting village, Quang Nam province, Vietnam. In: The 6th student research conference at Danang University, Vietnam 